\title{
Impact of Ducting on Heat Pump Water Heater Space Conditioning Energy Use and Comfort
}

SH Widder

GB Parker
JM Petersen

MC Baechler

July 2014

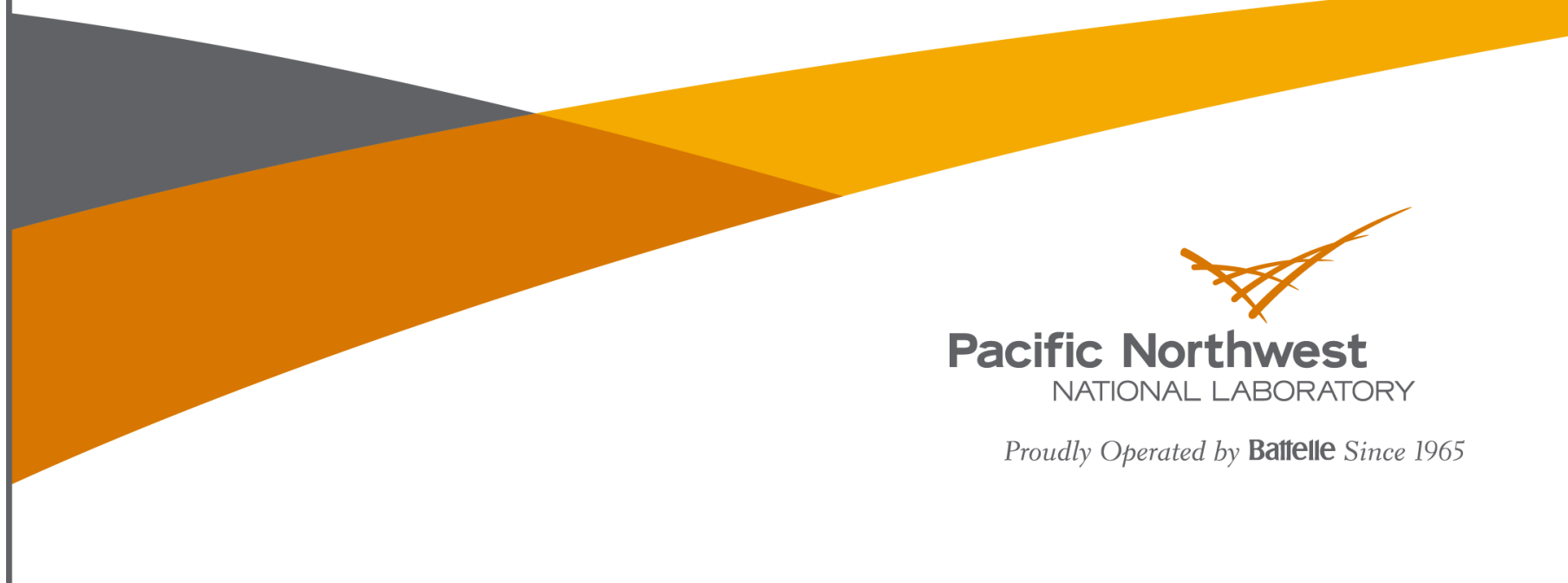




\title{
DISCLAIMER
}

This report was prepared as an account of work sponsored by an agency of the United States Government. Neither the United States Government nor any agency thereof, nor Battelle Memorial Institute, nor any of their employees, makes any warranty, express or implied, or assumes any legal liability or responsibility for the accuracy, completeness, or usefulness of any information, apparatus, product, or process disclosed, or represents that its use would not infringe privately owned rights. Reference herein to any specific commercial product, process, or service by trade name, trademark, manufacturer, or otherwise does not necessarily constitute or imply its endorsement, recommendation, or favoring by the United States Government or any agency thereof, or Battelle Memorial Institute. The views and opinions of authors expressed herein do not necessarily state or reflect those of the United States Government or any agency thereof.

\author{
PACIFIC NORTHWEST NATIONAL LABORATORY \\ operated by \\ BATTELLE \\ for the \\ UNITED STATES DEPARTMENT OF ENERGY \\ under Contract DE-AC05-76RL01830
}

Printed in the United States of America

Available to DOE and DOE contractors from the

Office of Scientific and Technical Information,

P.O. Box 62, Oak Ridge, TN 37831-0062;

ph: (865) 576-8401

fax: $(865)$ 576-5728

email: reports@adonis.osti.gov

Available to the public from the National Technical Information Service

5301 Shawnee Rd., Alexandria, VA 22312

ph: (800) 553-NTIS (6847)

email: orders@ntis.gov $<$ http://www.ntis.gov/about/form.aspx $>$

Online ordering: http://www.ntis.gov

This document was printed on recycled paper.

(8/2010) 


\title{
Impact of Ducting on Heat Pump Water Heater Space Conditioning Energy Use and Comfort
}

\author{
SH Widder \\ JM Petersen \\ GB Parker \\ MC Baechler
}

July 2014

Prepared for

the U.S. Department of Energy

under Contract DE-AC05-76RL01830

Pacific Northwest National Laboratory

Richland, Washington 99352 



\section{Summary}

Increasing penetration of heat pump water heaters (HPWHs) in the residential sector will offer an important opportunity for energy savings, with a theoretical energy savings of up to $63 \%$ per water heater ${ }^{1}$ and up to $11 \%$ of residential energy use (EIA 2009). However, several barriers must be overcome before this technology will reach widespread adoption in the Pacific Northwest region and nationwide. One significant barrier noted by the Northwest Energy Efficiency Alliance (NEEA) is the possible interaction with the homes' space conditioning systems for units installed in conditioned spaces. Such complex interactions may decrease the magnitude of whole-house savings available from HPWHs installed in the conditioned space in cold climates and could lead to comfort concerns (Larson et al. 2011; Kresta 2012). Modeling studies indicate that the installation location of HPWHs can significantly impact their performance and the resultant whole-house energy savings (Larson et al. 2012; Maguire et al. 2013). As a result, NEEA's Northern Climate HPWH Specification, which describes the characteristics a HPWH must have to be incentivized in cold climates in the Pacific Northwest, requires exhaust ducting for their Tier II-specified product and requires full ducting for a Tier III-specified product (NEEA 2013). ${ }^{2}$ However, field data are not currently available to substantiate these requirements. As installing HPWHs with exhaust or full ducting increases the cost and complexity of the HPWH installation, when it is required, such field data are necessary to verify modeling assumptions regarding the magnitude of interactions between the HPWH and the space conditioning system and to justify the need to install exhaust-only or full (supply and exhaust) ducting for HPWHs installed in conditioned space in cold climates.

This HPWH demonstration examines the overall performance of HPWHs installed in a conditioned space with a number of supply and/or exhaust ducting configurations, as well as the interactions between the HPWH and the home's heating/cooling system. Specifically, this field evaluation of two HPWHs in the Pacific Northwest National Laboratory Lab Homes is designed to measure the performance and impact on the Lab Home heating, ventilating and air conditioning (HVAC) system during heating and cooling season periods of HPWHs in two pairs of configurations:

1. a HPWH configured with exhaust ducting compared to an unducted HPWH

2. a HPWH with both supply and exhaust air ducting as compared to an unducted HPWH.

Important metrics evaluated in these experiments include water heater energy use, HVAC energy use, whole-house energy use, interior temperatures (as a proxy for thermal comfort), and cost impacts.

In general, the Lab Homes evaluation found that installing exhaust-only ducting on a HPWH in conditioned space increased whole-house energy use, while full ducting decreased whole-house energy use, as shown in Figure S.1. Specifically, the data from these experiments suggest that exhaust-only ducting increased space conditioning energy use $4.0 \pm 2.8 \%$ in the heating season as compared to the unducted HPWH, due to increased infiltration of colder outdoor air resulting from depressurization of the interior space. Full ducting was observed to substantially mitigate the impact of the HPWH on the

\footnotetext{
${ }^{1}$ Based on the DOE test procedure (10 CFR 430.32(d)) and comparison of an electric resistance water heater (Energy Factor, EF $=0.90)$ versus a HPWH $(\mathrm{EF}=2.4)$

${ }^{2}$ NEEA incorporates three product Tiers into their Northern Climate HPWH Specification to recognize variations in product performance and supported applications.
} 
HVAC system. The fully ducted HPWH decreased HVAC energy use $7.8 \pm 2.3 \%$ as compared to the Lab Home with an unducted HPWH.

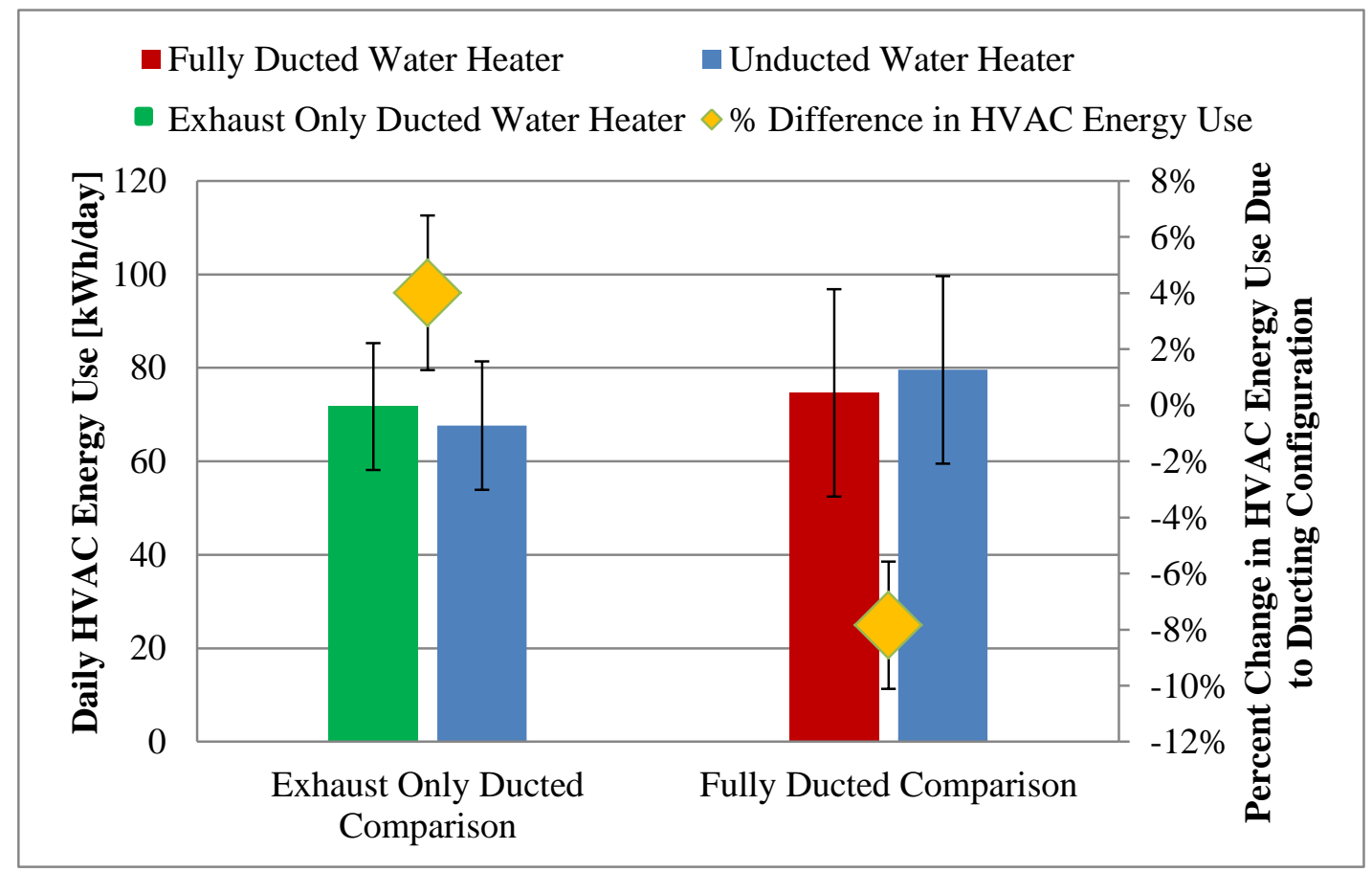

Figure S.1. Daily HVAC Energy Use (kWh/day) and Difference in HVAC Energy Use (\%) for the Exhaust-Only Ducted Comparison and the Fully Ducted Comparison Periods in the Heating Season

In addition, the experimental data indicate that the penalty of installing a HPWH in conditioned space may not be as large as modeling studies suggest, due to the buffering of interior walls resulting in localized cooling in the water heater closet, with very little impact on surrounding interior temperatures. Only approximately $43.4 \pm 12.2 \%$ of the theoretical space conditioning load was made up by the HVAC system in the heating season, and $37.2 \pm 4.7 \%$ cooling season. The study also verified the benefit of HPWHs installed in conditioned space in providing supplemental cooling, decreasing HVAC energy use by $9.3 \%$ compared to an exhaust-only or fully ducted HPWH. No significant impacts on interior temperatures were observed, as the cooling effect of the HPWH was largely localized in the water heater closet.

Although fully ducting the HPWH was observed to be an effective strategy to mitigate space conditioning impacts of HPWHs installed in conditioned space, this ducting configuration may also increase water heater energy use due to cooler supply air temperatures. This study shows that cooler crawlspace temperatures increased water heater energy use $4.3 \pm 1.8 \%$ for the HPWH operating in "Heat Pump" mode; however, this incremental difference is small compared to the difference in HVAC energy use accomplished by the different ducting configurations.

Therefore, from a whole-house perspective, the net energy impacts of HPWHs installed in conditioned spaces are driven by the HVAC system interaction, as shown in Table S.1. Similarly, the cost-effectiveness of installing ducting on HPWHs will be driven by the HVAC system interaction. In this experiment, full ducting provided a lifetime energy savings of $\$ 1,982$ compared to an unducted 
HPWH over an assumed 10-year life of the water heater. This corresponds to a decrease in whole-house energy costs of approximately $4.2 \%$. Conversely, the exhaust-only ducting increased total energy costs by $\$ 1,306$, or $2.9 \%$, compared to the same unducted HPWH over a 10-year lifetime in Richland's heatingdominated climate. Table S.1 also provides the estimated annual energy and cost impacts when the maximum possible, or theoretical, HPWH space conditioning interaction is assumed, for comparison. The magnitude of these energy cost impacts far outweigh the cost of full ducting assumed in this analysis.

Table S.1. Annual Difference in HVAC, Water Heater, and Whole-House Energy Use (kWh/yr and \%) and Associated Energy Costs Calculated Based on the Experimental Data and the "Theoretical" Difference in HVAC Energy Use

\begin{tabular}{|c|c|c|c|c|c|}
\hline & \multicolumn{5}{|c|}{ Annual Difference in } \\
\hline & $\begin{array}{c}\text { HVAC Energy Use } \\
k W h / y r \\
(\%)^{*} \\
\end{array}$ & $\begin{array}{c}\text { Water Heater } \\
\text { Energy Use } \\
k W h / y r \\
(\%) * \\
\end{array}$ & $\begin{array}{c}\text { Whole-House } \\
\text { Energy Use } \\
k W h / y r \\
(\%)^{*}\end{array}$ & $\begin{array}{c}\text { Energy Cost } \\
\$ / y r \\
(\%) * \\
\end{array}$ & $\begin{array}{l}\text { Lifetime } \\
\text { Cost } \\
\$\end{array}$ \\
\hline $\begin{array}{l}\text { Exhaust-Only } \\
\text { Comparison }\end{array}$ & $\begin{array}{l}858 \pm 440 \\
(6.2 \pm 3.2)\end{array}$ & $\begin{array}{c}-144 \pm 74 \\
(-6.8 \pm 3.5)\end{array}$ & $\begin{array}{l}714 \pm 446 \\
(2.9 \pm 1.8)\end{array}$ & $\begin{array}{r}86 \\
(2.9)\end{array}$ & 1,306 \\
\hline $\begin{array}{l}\text { Fully Ducted } \\
\text { Comparison }\end{array}$ & $\begin{array}{c}-1079 \pm 408 \\
(-7.8 \pm 3.0)\end{array}$ & $\begin{array}{c}48 \pm 49 \\
(2.3 \pm 2.3)\end{array}$ & $\begin{array}{c}-1031 \pm 411 \\
(-4.2 \pm 1.7)\end{array}$ & $\begin{array}{l}-125 \\
(-4.2)\end{array}$ & $-1,982$ \\
\hline $\begin{array}{l}\text { Theoretical } \\
\text { Exhaust-Only } \\
\text { Comparison }\end{array}$ & $\begin{array}{c}1953 \pm 1056 \\
(14.1 \pm 7.6)\end{array}$ & $\begin{array}{l}-144 \pm 74 \\
(-6.8 \pm 3.5)\end{array}$ & $\begin{array}{c}1809 \pm 1059 \\
(7.3 \pm 4.3)\end{array}$ & $\begin{array}{r}219 \\
(7.3)\end{array}$ & 2,192 \\
\hline $\begin{array}{l}\text { Theoretical Fully } \\
\text { Ducted } \\
\text { Comparison }\end{array}$ & $\begin{array}{l}-2210 \pm 928 \\
(-16.0 \pm 6.7)\end{array}$ & $\begin{array}{c}48 \pm 49 \\
(2.3 \pm 2.3)\end{array}$ & $\begin{array}{c}-2162 \pm 930 \\
(-8.8 \pm 3.8)\end{array}$ & $\begin{array}{l}-262 \\
(-8.8)\end{array}$ & $-2,620$ \\
\hline
\end{tabular}

* Percentage difference in annual energy use estimates are presented as a percent of that equipment load (e.g., the annual difference in HVAC energy use is presented as a percentage of HVAC energy usage).

However, to validate these findings and further explore the depressurizations caused by the HPWH with exhaust-only ducting, repeating similar experiments with spatial measurement of differential pressure could identify key sources of infiltration. In addition, conducting an experiment to precisely evaluate the effect of inside walls on buffering of thermal loads could help validate or refute the findings related to the relative magnitude of the interaction between the HPWH and HVAC system, compared to the maximum theoretical interaction. Such inputs could be used to develop more detailed modeling using a multi-zone energy model to validate space interactions of HPWH duct configurations. A calibrated model could then be used to evaluate variability with climate and the relative impacts with different heating and cooling system assumptions. This additional modeling, and associated cost analysis, of HPWH and space conditioning system interactions for a variety of climate zones, HVAC system types, and HPWH operating modes is necessary to assess the cost-effectiveness of ducting and to make formal recommendations regarding appropriate installation of HPWHs under more diverse scenarios. 



\section{Acknowledgments}

This project was funded by the U.S. Department of Energy, Energy Efficiency and Renewable Energy Building America Program (Eric Werling and Sam Rashkin, Program Managers); the Bonneville Power Administration (Kacie Bedney, Stephanie Vasquez, and Janice Peterson (Contractor); Project Managers); and the U.S. Department of Energy, Office of Electricity Delivery and Energy Reliability (Dan Ton, Program Manager). Additional support was provided by the project partners Northwest Energy Works (Tom Hews/Brady Peeks) and GE Appliances (Scott Schaeffer).

The authors also wish to acknowledge the contributions of other PNNL staff: Susan Sande for her assistance in procuring equipment and overseeing the Lab Homes modifications, Jamie Spangle for her financial expertise, Maura Zimmerschied for editorial support, Todd Samuel for his consistent and significant management support, Marye Hefty for her leadership and intuition, Nathan Bauman for his metering expertise, Spencer Gilbride and Austin Winkelman for their assistance in implementing experiments, and other Lab Homes researchers who accommodated this experiment and abided by the schedule.

The authors also acknowledge the technical support provided by Greg Sullivan, Principal, Efficiency Solutions, LLC, Richland, Washington, for assistance with occupancy simulation development, metering, and data collection. 


\title{
Acronyms and Abbreviations
}

\author{
$\mathrm{ACH}_{\mathrm{n}}$ \\ ACH50 \\ ASHP \\ BA \\ Btu \\ $\mathrm{C}_{\mathrm{p} \text {,water }}$ \\ CFM \\ Cooling Cap ${ }_{\text {HPWH }}$ \\ CoolingInput \\ COP \\ $\mathrm{COP}_{\mathrm{HPWH}}$ \\ DR \\ EF \\ ERWH \\ gal/day \\ gpm \\ GE \\ HPWH \\ HVAC \\ $\mathrm{kW}$ \\ $\mathrm{kWh}$ \\ LBNL \\ NEEA \\ NREL \\ $\mathrm{P}_{\mathrm{ON}, \mathrm{HPWH}}$ \\ $\mathrm{PA}_{\mathrm{HPWH}}$ \\ PNNL \\ SEEM \\ $\mathrm{Q}_{\text {HPWH }}$ \\ $\mathrm{Q}_{\text {HVAC }}$ \\ $\mathrm{Q}_{\text {water }}$ \\ RE \\ SEER \\ air changes per hour natural \\ air changes per hour at 50 Pascals of depressurization with respect to the outside \\ air source heat pump \\ Building America \\ British thermal unit \\ specific heat capacity of water $\left(1 \mathrm{Btu} / \mathrm{lb} \cdot{ }^{\circ} \mathrm{F}\right.$ or $\left.0.2931 \mathrm{Wh} / \mathrm{lb} \cdot{ }^{\circ} \mathrm{F}\right)$ \\ cubic feet per minute \\ cooling capacity of heat pump water heater \\ the amount of cooling added by the heat pump water heater in Btu/h \\ coefficient of performance \\ system coefficient of performance of the HPWH; a ratio of the energy delivered \\ as hot water to the electrical energy provided to the equipment \\ demand response \\ energy factor \\ electric resistance water heater \\ gallons per day \\ gallons per minute \\ General Electric \\ heat pump water heater \\ heating, ventilating and air conditioning \\ kilowatt \\ kilowatt-hour \\ Lawrence Berkeley National Laboratory \\ Northwest Energy Efficiency Alliance \\ National Renewable Energy Laboratory \\ rated input power to the water heater in Btu/h \\ performance adjustment factor that accounts for the impact of ambient \\ temperature on the efficiency of the HPWH \\ Pacific Northwest National Laboratory \\ a residential energy use modeling program developed by Ecotope \\ heat pump water heater energy consumption \\ thermal energy provided from the conditioned space \\ thermal energy provided as hot water \\ recovery efficiency as measured by the DOE test procedure for residential water \\ heaters (10 CFR 430.23) in percent \\ seasonal energy efficiency ratio
}




$\begin{array}{ll}\mathrm{T}_{\text {out }} & \text { outlet water temperature in }{ }^{\circ} \mathrm{F} \\ \mathrm{T}_{\text {in }} & \text { inlet water temperature in }{ }^{\circ} \mathrm{F} \\ \mathrm{T}_{\text {in,air }} & \text { indoor air temperature in }{ }^{\circ} \mathrm{F} ; \\ \mathrm{T}_{\text {tank }} & \text { set point of tank thermostat in }{ }^{\circ} \mathrm{F} \\ \mathrm{V}_{\text {water }} & \text { the average daily hot water volume drawn in gallons } \\ \mathrm{W} & \text { watt } \\ \mathrm{Wh} & \text { watt-hour } \\ \mathrm{WH} & \text { water heater } \\ \rho & \text { density of water in pounds per gallon }(8.34 \mathrm{lb} / \mathrm{gal})\end{array}$





\section{Contents}

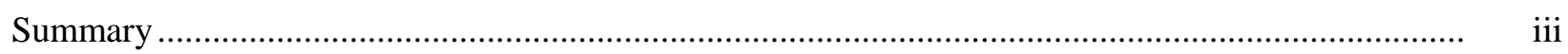

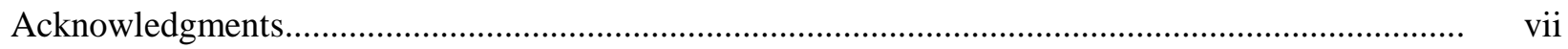

Acronyms and Abbreviations ................................................................................................. viii

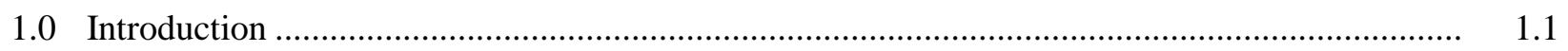

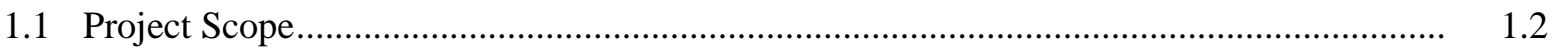

2.0 Background on Space Conditioning Interaction of Heat Pump Water Heaters Installed in

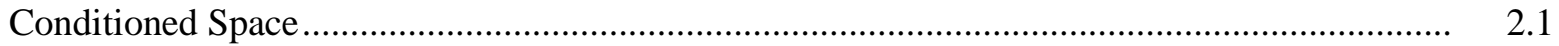

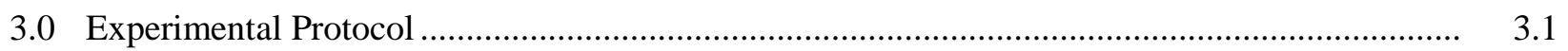

3.1 GE Generation II GeoSpring Hybrid Water Heater ........................................................ 3.1

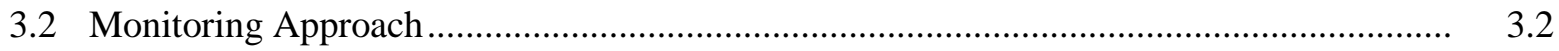

3.2.1 Electrical Measurements ............................................................................. 3.4

3.2.2 Temperature and Environmental Sensors........................................................... 3.4

3.2.3 Data Acquisition System ................................................................................ 3.5

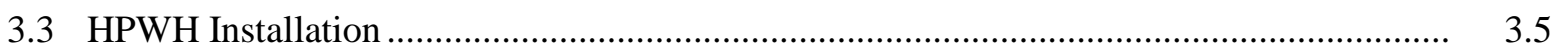

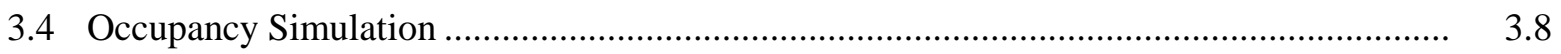

3.4.1 Electrical Loads.............................................................................................. 3.8

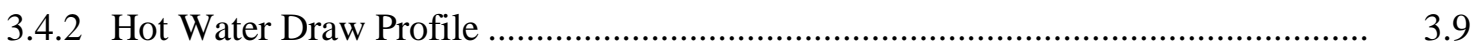

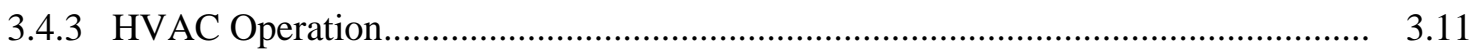

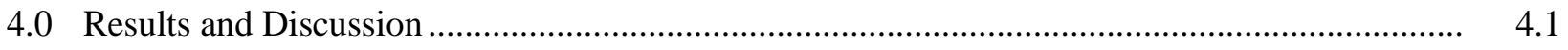

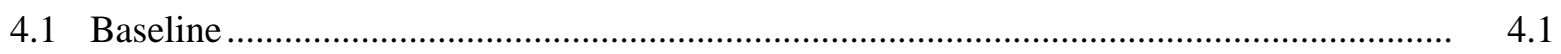

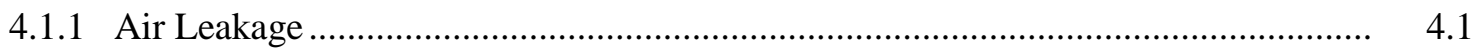

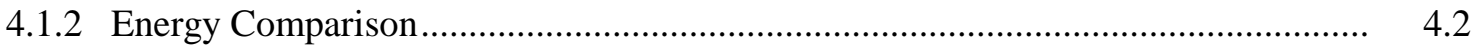

4.2 Impacts of Various Ducting Configurations on HVAC Energy Use ................................ 4.4

4.2.1 Cooling Season HVAC Energy Use Impacts ......................................................... 4.4

4.2.2 Heating Season HVAC Energy Use Impacts ....................................................... 4.5

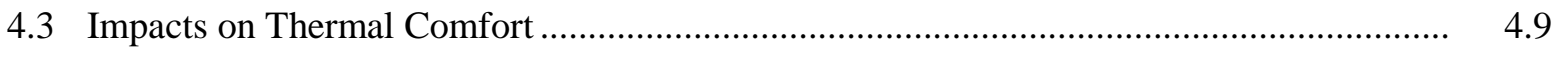

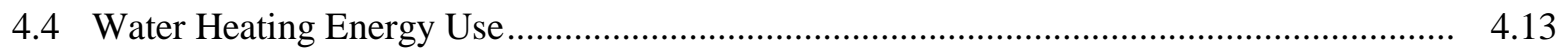

4.5 Whole-House Energy Impacts and Cost-Effectiveness................................................... 4.16

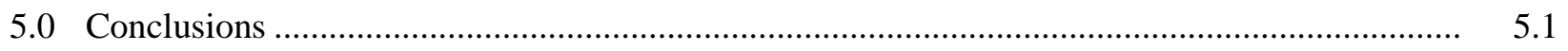

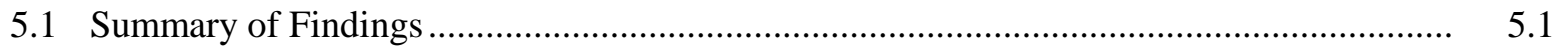

5.2 Recommendations and Future Experiments.................................................................. 5.2

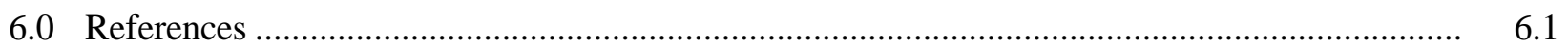




\section{Figures}

S.1 Daily HVAC Energy Use and Difference in HVAC Energy Use for the Exhaust-Only Ducted Comparison and the Fully Ducted Comparison Periods in the Heating Season

3.1 Diagram of Key Components in a Unitary HPWH............................................................ 3.1

3.2 Crawlspace Thermocouple Locations ................................................................................. 3.4

3.3 GE Gen-II GeoSpring HPWH Installed in Lab Home Water Heater Closet .............................. 3.6

3.4 Transfer Grille and Thermostat Locations. Left: transfer grilles installed between water heater closet and adjacent master bedroom closet. .................................................................. 3.6

3.5 Left: Exhaust Ducting Approach on HPWH. Right: Supply Ducting Configuration on the HPWH.

4.1 Comparison of Cumulative HVAC Energy Use of Lab Home A versus Lab Home B

4.2 Average Daily Water Heater Energy Use Profile for Lab Home A and Lab Home B in Heat Pump Mode.

4.3 Daily HVAC Energy Use and Difference in HVAC Energy Use for the Exhaust-Only Ducted Comparison and the Fully Ducted Comparison Periods in the Cooling Season

4.4 Daily HVAC Energy Use and Difference in HVAC Energy Use for the Exhaust-Only Ducted Comparison and the Fully Ducted Comparison Periods in the Heating Season

4.5 Comparisons in the Heating Season and Cooling Season of Average HPWH Energy Usage, Average Daily Thermal Energy Provided as Hot Water, Average Theoretical Contribution to Hot Water Thermal Energy Provided by the Space, and the Average Difference in Daily HVAC Energy Use in Lab Home B with an Unducted HPWH Compared to Lab Home A with a Fully Ducted HPWH

4.6 Water Heater Closet and Master Bedroom Interior Temperatures for Lab Home A and Lab Home B for Six Days.

4.7 Average Temperature and Standard Deviation in Each Room During the Exhaust-Only Ducted Comparison Period in the Cooling Season.

4.8 Average Temperature and Standard Deviation in Each Room During the Fully Ducted Comparison Period in the Cooling Season

4.9 Average Temperature and Standard Deviation in Each Room During the Exhaust-Only Ducted Comparison Period in the Heating Season

4.10 Average Temperature and Standard Deviation in Each Room During the Fully Ducted Comparison Period in the Heating Season.

4.11 Average Daily HPWH Energy Use During Exhaust-Only Comparison and Fully Ducted Comparison Periods in the Cooling Season....

4.12 Average Daily HPWH Energy Use During Exhaust-Only Comparison and Fully Ducted Comparison Periods in the Heating Season.

4.13 HPWH Outlet Temperature and Tank Temperature for the Fully Ducted and Exhaust-Only Cases. 


\section{Tables}

S.1 Annual Difference in HVAC, Water Heater, and Whole-House Energy Use and Associated Energy Costs Calculated Based on the Experimental Data and the "Theoretical" Difference in HVAC Energy Use

2.1 Components of Net Annual Source Energy Savings by BA Climate Zone When Replacing an ERWH with a 50 gal HPWH Installed in Conditioned Space with Electric Resistance Heat and Air Conditioning as the Heating and Cooling System.

2.2 Components of Net Annual Source Energy Savings by BA Climate Zone When Replacing an ERWH with a 50 gal HPWH Installed in Conditioned Space with an ASHP as the Heating and Cooling System.

2.3 Comparison of Water Heating Energy Savings and HVAC System Interactions and Percentage Change in Net Energy Savings Due to HVAC System Interactions.

3.1 Metering Strategy and Equipment

3.2 Domestic Hot Water Heater Daily Use by End Use..

4.1 Building Envelope Leakage as Measured by Blower Door Tests in the Baseline and Experimental Homes.

4.2 Average and Standard Deviation of the Water Heater Closet Temperature in the Heating and Cooling Seasons for the Exhaust-Only Ducted and Fully Ducted Comparisons

4.3 Average and Standard Deviation of Interior Temperatures Measured in the Main Body of the House and the HPWH Closet Temperature in the Heating Season and Cooling Season for the Exhaust-Only Ducted and Fully Ducted Comparisons

4.4 Annual Difference in HVAC, Water Heater, and Whole-House Energy Use and Associated Energy Costs Calculated Based on the Experimental Data and the "Theoretical" Difference in HVAC Energy Use 



\subsection{Introduction}

Water heating represents approximately $18 \%$ of residential energy consumption, or 4.6 quadrillion Btus of source energy use annually (EIA 2009) and efficient water heater options are necessary to achieve significant energy savings in the residential sector. Heat pump water heaters (HPWHs) offer an efficient option for the $41 \%$ of homes with electrically heated water heaters, with a theoretical energy savings of up to $63 \% .^{3}$ Previous research has demonstrated the laboratory performance of HPWHs and has shown savings of 47 to $63 \%$ are possible, based on standardized testing protocols (Larson et al. 2011).

The HPWH is the largest savings measure in the residential sector in the Northwest Power and Conservation Council's Sixth Northwest Power Plan at 492 average megawatts (Northwest Power and Conservation Council 2010). There is also considerable energy savings potential nationwide for HPWH technology. The nationwide installed base of electric water heaters is 46.8 million units (EIA 2009). If only $10 \%$ of these water heaters were replaced with HPWHs that meet ENERGY STAR criteria, the annual savings are estimated to be as much as 22 billion kilowatt-hours $(\mathrm{kWh})$ and $\$ 2.7$ billion in customer electricity bills.

However, significant barriers must be overcome before this technology can reach widespread adoption in the Pacific Northwest region and nationwide. One significant barrier noted by the Northwest Energy Efficiency Alliance (NEEA) is the possible interaction with the homes' space conditioning systems for units installed in conditioned spaces. Such complex interactions may decrease the magnitude of whole-house savings available from HPWHs installed in the conditioned space in cold climates and could lead to comfort concerns (Larson et al. 2011; Kresta 2012). Modeling studies indicate that the installation location of HPWHs can significantly impact their performance and the resultant whole-house energy savings (Larson et al. 2012; Maguire et al. 2013). As a result, NEEA's Northern Climate HPWH Specification, which describes the characteristics a HPWH must have to be incentivized in cold climates in the Pacific Northwest, requires exhaust ducting for their Tier II-specified product (NEEA 2013). ${ }^{4}$ There are currently only two manufacturers offering a total of five models of equipment meeting NEEA's Tier II specification (NEEA 2014).

In addition, if exhaust ducting on HPWHs is required or otherwise installed in some or all climates, it will also be important to understand the source of supply air and the implications for interior depressurization, particularly for tight homes and homes in high-radon areas. NEEA's Northern Climate HPWH Specification requires full ducting for a Tier III-specified product (NEEA 2013) and new Northwest Energy Efficient Manufactured Housing specifications may necessitate similar requirements (Larson and Hewes 2012). There are currently no manufacturers that offer equipment certified to meet NEEA's Tier III specification (NEEA 2014). However, the AirGenerate is now available with intake and exhaust ducting (AirGenerate 2014) and intake/outlet duct adapter kits are available from State Water Heaters (State Water Heaters 2012).

\footnotetext{
${ }^{3}$ Based on the DOE test procedure (10 CFR 430.32(d)) and comparison of an ERWH (Energy Factor, EF $=0.90$ ) versus a HPWH $(\mathrm{EF}=2.4)$

${ }^{4}$ NEEA incorporates three product Tiers into their Northern Climate HPWH Specification to recognize variations in product performance and supported applications.
} 
Installing HPWHs with exhaust or full ducting increases the cost and complexity of the HPWH installation, when it is required. Field data are necessary to verify modeling assumptions regarding the magnitude of interactions between the HPWH and space conditioning system to justify the need to install exhaust-only or full (supply and exhaust) ducting for HPWHs installed in conditioned space in cold climates.

Another barrier to widespread HPWH market penetration is the impact of HPWHs on demandresponse (DR) programs, since HPWH DR characteristics are currently unknown. Many utilities currently employ electric resistance water heaters (ERWHs) to reduce peak load by turning off the water heater during times of peak demand. Some utilities are also demonstrating the potential of using HPWHs to increase load for areas with high renewable energy penetration and to provide additional balancing and ancillary (voltage regulation) services. There is a need to understand DR characteristics of HPWHs as compared to ERWHs, including dispatchable kilowatts $(\mathrm{kW})$, thermal capacity, and response time, to effectively integrate HPWHs with utility DR programs.

\subsection{Project Scope}

This HPWH demonstration examines the overall performance of HPWHs installed in a conditioned space with a number of supply and/or exhaust ducting configurations, as well as the interactions between the HPWH and the home's heating/cooling system. Space conditioning impacts of HPWHs include the impact on the heating, ventilating and air conditioning (HVAC) system and thermal comfort issues that could affect occupant satisfaction and market acceptance of these technologies. The project compares the performance of a HPWH with no ducting, exhaust ducting, and full ducting (supply and exhaust) under identical occupancy schedules and hot water draw profiles in the Pacific Northwest National Laboratory (PNNL) Lab Homes. The following sections describe the experimental protocol and test apparatus used to collect data, present the baselining procedure, discuss the results of each experiment, and provide key conclusions based on the collected data for the space conditioning experiments.

In addition, this project characterized the DR of this second-generation HPWH to various price signals. The results of the DR experiments are reported separately (Widder et al. 2013). 


\subsection{Background on Space Conditioning Interaction of Heat Pump Water Heaters Installed in Conditioned Space}

The current understanding regarding the interaction of HPWHs with space conditioning systems and current recommendations regarding the installation of ducting in cold climate systems are based on theoretical models that have not been verified by field data.

The National Renewable Energy Laboratory (NREL) has developed modeling capabilities for HPWHs within the BEopt ${ }^{\mathrm{TM}}$ (Building Energy Optimization) software using the EnergyPlus simulation engine, which calculates results on an hourly basis and includes transient effects (Wilson and Christensen 2012). Ecotope has also updated the SEEM energy $\operatorname{model}^{5}$ to include HPWH and space conditioning interactions (Larson et al. 2011). In addition, in the 2010 residential water heater energy conservation standard final rule (75 FR 20112 (April 16, 2010)), The U.S. Department of Energy (DOE) accounted for HVAC interactions when calculating the savings associated with HPWHs (DOE 2010).

In general, these models appear to assume a complete energy balance around the water heater. That is, $100 \%$ of the thermal energy provided as hot water $\left(\mathrm{Q}_{\text {water }}\right)$ is provided by both the water heater electrical energy consumption $\left(\mathrm{Q}_{\mathrm{HPWH}}\right)$ and thermal energy from the surrounding conditioned space (Q $\left.\mathrm{QHAC}_{\mathrm{H}}\right)$, as shown in Equation 1:

$$
\mathrm{Q}_{\text {water }}=\mathrm{Q}_{\mathrm{HPWH}}+\mathrm{Q}_{\mathrm{HVAC}}
$$

The calculations that occur in the EnergyPlus and SEEM energy models are typically dynamic hourly simulations that also model standby losses from the tank and related impacts on interior temperatures. However, from a simple energy balance perspective the standby losses can be ignored.

The thermal energy provided as hot water can be determined using Equation 2, as follows:

$$
\mathrm{Q}_{\text {water }}=\mathrm{V}_{\text {water }} \times \rho \times \mathrm{C}_{\mathrm{p}, \mathrm{water}} \times\left(\mathrm{T}_{\text {out }}-\mathrm{T}_{\text {in }}\right) / 1000
$$

where

$$
\begin{aligned}
\mathrm{Q}_{\text {water }} & =\text { the energy provided to the water in } \mathrm{kWh} \\
\mathrm{V}_{\text {water }} & =\text { the average daily hot water volume drawn in gallons } \\
\mathrm{T}_{\text {out }} & =\text { the measured outlet water temperature in }{ }^{\circ} \mathrm{F} \\
\rho & =\text { the density of water in pounds per gallon }(8.34 \mathrm{lb} / \mathrm{gal}) \\
\mathrm{C}_{\mathrm{p} \text {,water }} & =\text { the specific heat capacity of water }\left(1 \mathrm{Btu} / \mathrm{lb} \cdot{ }^{\circ} \mathrm{F} \text { or } 0.2931 \mathrm{Wh} / \mathrm{lb} \cdot{ }^{\circ} \mathrm{F}\right) \\
\mathrm{T}_{\text {in }} & =\text { the measured inlet water temperature in }{ }^{\circ} \mathrm{F} .
\end{aligned}
$$

The electrical energy provided as hot water is modeled directly, based on the performance of the HPWH as a function of surrounding ambient temperature, the temperature of the hot water tank, and the

\footnotetext{
${ }^{5}$ The SEEM program is designed to model small-scale residential building energy use. The program consists of an hourly thermal simulation and an hourly moisture (humidity) simulation that interacts with duct specifications, equipment, and weather parameters to calculate the annual heating and cooling energy requirements of the building. SEEM, written at Ecotope, was developed by and for the Council and NEEA. SEEM is used extensively in the Northwest to estimate conservation measure savings for regional energy utility policy planners. For more information, see http://rtf.nwcouncil.org//measures/support/seem/.
} 
frequency and magnitude of hot water draws. The thermal energy contribution from the surrounding conditioned space, which is made up by the HVAC system, can then be determined as the difference between these two quantities, as indicated by Equation 1.

Note that the relative energy consumed as electricity, versus that transferred from the space, is a function of the efficiency of the water heater. The coefficient of performance of the HPWH $\left(\mathrm{COP}_{\mathrm{HPWH}}\right)$ is a measure of the thermal energy provided to the water versus the electrical energy consumed by the HPWH, as shown in Equation 3:

$$
C O P_{H P W H}=\frac{Q_{w a t e r}}{Q_{H P W H}}
$$

Therefore, the total thermal energy provided as hot water and the thermal load on the space $\left(\mathrm{Q}_{\mathrm{HVAC}}\right)$ can also be calculated as a function of the efficiency of the water heater, as shown in Equations 4 and 5:

$$
\begin{aligned}
& \mathrm{Q}_{\text {water }}=\mathrm{Q}_{\mathrm{HPWH}} \times \mathrm{COP}_{\mathrm{HPWH}} \\
& \mathrm{Q}_{\mathrm{HVAC}}=\mathrm{Q}_{\mathrm{HPWH}} \times\left(\mathrm{COP}_{\mathrm{HPWH}}-1\right)
\end{aligned}
$$

In Chapter 7 of the technical support document for the 2010 residential water heater energy conservation standard final rule, DOE describes a similar calculation to determine a rate of cooling introduced to the space, or heat removed from the space (DOE 2010). Specifically, DOE defined the "cooling input" as described in Equation 6:

$$
\text { Cooling Input }=\text { Cooling Capacity }{ }_{H P W H} \times \frac{V_{w a t e r} \times \rho \times C_{p}\left(T_{\text {tank }}-T_{\text {in, air }}\right)}{P_{O N, H P W H} \times R E_{H P W H} \times P A_{H P W H}}
$$

where

CoolingInput $=$ the amount of cooling added by the heat pump water heater in Btu/h

$\mathrm{T}_{\text {tank }}=$ the set point of tank thermostat in ${ }^{\circ} \mathrm{F}$

$\mathrm{T}_{\text {in,air }}=$ the indoor air temperature in ${ }^{\circ} \mathrm{F}$

$\mathrm{P}_{\mathrm{ON}, \mathrm{HPWH}}=$ the rated input power to the water heater in $\mathrm{Btu} / \mathrm{h}$

$R E=$ the recovery efficiency as measured by the $\mathrm{DOE}$ test procedure for residential water heaters (10 CFR 430.23) in \%

$\mathrm{PA}_{\mathrm{HPWH}}=$ the performance adjustment factor that accounts for the impact of ambient temperature on the efficiency of the HPWH

Cooling Cap $_{H P W H}=$ the cooling capacity of heat pump water heater

and $\rho, \mathrm{C}_{\mathrm{p}}$, and $\mathrm{V}_{\text {water }}$ are as previously defined. Modeling based on these assumptions has demonstrated that space heating penalties can significantly reduce potential savings in cold climates, depending on the type of heating system installed in the home.

NREL estimates that the heating system impact can decrease savings from a HPWH 33-67\% if the home is heated by an electric resistance furnace (Maguire et al. 2013). The colder climates will experience the most significant impact, while the warmer climates will experience smaller impacts because they are heating for less of the year, as shown in Table 2.1. This is observed as the change in space heating in energy use increases in colder climate zones. Conversely, the change in space cooling energy use decreases in colder climates. However, the change in space cooling energy is much smaller than the change in space heating energy use, due to the relative efficiency of the heating and cooling 
systems. When the space cooling benefit is accounted for, the total change in net energy savings due to HVAC system interactions ranges from a decrease of 14 to $63 \%$ of the water heating energy savings from the HPWH alone.

Table 2.1. Components of Net Annual Source Energy Savings (in MMBtu) by BA ${ }^{(a)}$ Climate Zone When Replacing an ERWH with a 50 gal HPWH Installed in Conditioned Space with Electric Resistance Heat and Air Conditioning as the Heating and Cooling System. Source: Maguire et al. 2013.

\begin{tabular}{|c|c|c|c|c|c|c|c|}
\hline $\begin{array}{c}\text { BA } \\
\text { Climate } \\
\text { Zone }\end{array}$ & $\begin{array}{l}\text { COP } \\
\text { HPWH }\end{array}$ & $\begin{array}{c}\text { Change } \\
\text { in } \\
\text { Water } \\
\text { Heating } \\
\text { Energy } \\
\text { Use } \\
\text { HPWH } \\
\end{array}$ & $\begin{array}{l}\text { Change in } \\
\text { Space } \\
\text { Heating } \\
\text { Energy } \\
\text { Use }\end{array}$ & $\begin{array}{c}\text { Percent } \\
\text { Change in } \\
\text { Water } \\
\text { Heating } \\
\text { Savings Due } \\
\text { to Heating } \\
\text { Penalty }^{(b)} \\
\end{array}$ & $\begin{array}{c}\text { Change in } \\
\text { Space } \\
\text { Cooling } \\
\text { Energy Use }\end{array}$ & $\begin{array}{c}\text { Percent } \\
\text { Change in } \\
\text { Change in } \\
\text { Water Heating } \\
\text { Savings Due to } \\
\text { Cooling } \\
\text { Benefit }^{\text {b) }} \\
\end{array}$ & $\begin{array}{l}\text { Total Percent } \\
\text { Change in Net } \\
\text { Water Heating } \\
\text { Savings Due to } \\
\text { HVAC System } \\
\text { Interactions }^{\left({ }^{b}\right)}\end{array}$ \\
\hline $\begin{array}{l}\text { Hot- } \\
\text { Humid }\end{array}$ & 2.0 & -16.59 & 5.44 & $-32.79 \%$ & -3.14 & $18.93 \%$ & $-13.86 \%$ \\
\hline $\begin{array}{l}\text { Mixed- } \\
\text { Humid }\end{array}$ & 1.9 & -19.38 & 10.08 & $-52.01 \%$ & -2.22 & $11.46 \%$ & $-40.56 \%$ \\
\hline Hot-Dry & 1.7 & -17.08 & 8.32 & $-48.71 \%$ & -1.90 & $11.12 \%$ & $-37.59 \%$ \\
\hline $\begin{array}{l}\text { Mixed- } \\
\text { Dry }\end{array}$ & 1.5 & -18.79 & 9.97 & $-53.06 \%$ & -1.62 & $8.62 \%$ & $-44.44 \%$ \\
\hline Marine & 1.7 & -20.72 & 15.44 & $-74.52 \%$ & -0.52 & $2.51 \%$ & $-72.01 \%$ \\
\hline Cold & 1.6 & -21.01 & 12.66 & $-60.26 \%$ & -1.49 & $7.09 \%$ & $-53.17 \%$ \\
\hline $\begin{array}{l}\text { Very } \\
\text { Cold }\end{array}$ & 1.5 & -22.47 & 14.95 & $-66.53 \%$ & -0.91 & $4.05 \%$ & $-62.48 \%$ \\
\hline
\end{tabular}

(a) $\mathrm{BA}=$ Building America

(b) A positive change in water heating energy savings indicates increased savings (decreased energy use), while a negative change in water heater energy savings indicates decreased savings (increased use) as compared to the modeled water heater energy savings from the HPWH without accounting for the space conditioning impact.

If the home is heated by a heat pump, the space conditioning impact is reduced as a function of the efficiency of the heating system. For an air source heat pump (ASHP) with a seasonal energy efficiency ratio (SEER) of 13, NREL demonstrated the space conditioning impact was reduced by more than half to between 11 and 35\%, depending on the climate zone, as shown in Table 2.2. 
Table 2.2. Components of Net Annual Source Energy Savings (in MMBtu) by BA Climate Zone When Replacing an ERWH with a 50 gal HPWH Installed in Conditioned Space with an ASHP as the Heating and Cooling System. Source: Maguire et al. 2013.

\begin{tabular}{|c|c|c|c|c|c|c|c|}
\hline $\begin{array}{c}\text { BA } \\
\text { Climate } \\
\text { Zone }\end{array}$ & $\mathrm{COP}_{\text {HPWH }}$ & $\begin{array}{c}\text { Change } \\
\text { in } \\
\text { Water } \\
\text { Heating } \\
\text { Energy } \\
\text { Use } \\
\text { HPWH }\end{array}$ & $\begin{array}{c}\text { Change } \\
\text { in Space } \\
\text { Heating } \\
\text { Energy } \\
\text { Use }\end{array}$ & $\begin{array}{c}\text { Percent } \\
\text { Change in } \\
\text { Water } \\
\text { Heating } \\
\text { Savings Due } \\
\text { to Heating } \\
\text { Penalty }^{(a)}\end{array}$ & $\begin{array}{c}\text { Change in } \\
\text { Space } \\
\text { Cooling } \\
\text { Energy } \\
\text { Use }\end{array}$ & $\begin{array}{c}\text { Percent } \\
\text { Change in } \\
\text { Change in } \\
\text { Water } \\
\text { Heating } \\
\text { Savings Due } \\
\text { to Cooling } \\
\text { Benefit }^{(\mathbf{a})}\end{array}$ & $\begin{array}{c}\text { Total Percent } \\
\text { Change in Net } \\
\text { Water Heating } \\
\text { Savings Due to } \\
\text { HVAC System } \\
\text { Interactions }^{(a)}\end{array}$ \\
\hline $\begin{array}{l}\text { Hot- } \\
\text { Humid }\end{array}$ & 2.0 & -16.98 & 1.90 & $-11.19 \%$ & -3.65 & $21.50 \%$ & $10.31 \%$ \\
\hline $\begin{array}{l}\text { Mixed- } \\
\text { Humid }\end{array}$ & 1.9 & -19.78 & 4.17 & $-21.08 \%$ & -2.54 & $12.84 \%$ & $-8.24 \%$ \\
\hline Hot-Dry & 1.7 & -17.5 & 2.79 & $-15.94 \%$ & -2.15 & $12.29 \%$ & $-3.66 \%$ \\
\hline $\begin{array}{l}\text { Mixed- } \\
\text { Dry }\end{array}$ & 1.5 & -19.19 & 4.28 & $-22.30 \%$ & -1.79 & $9.33 \%$ & $-12.98 \%$ \\
\hline Marine & 1.7 & -21.13 & 5.28 & $-24.99 \%$ & -0.59 & $2.79 \%$ & $-22.20 \%$ \\
\hline Cold & 1.6 & -21.41 & 6.16 & $-28.77 \%$ & -1.68 & $7.85 \%$ & $-20.92 \%$ \\
\hline $\begin{array}{l}\text { Very } \\
\text { Cold }\end{array}$ & 1.5 & -22.84 & 8.09 & $-35.42 \%$ & -1.03 & $4.51 \%$ & $-30.91 \%$ \\
\hline
\end{tabular}

The cooling system interaction is typically smaller than the heating system interaction due to the efficiency of the refrigeration cycle in air-conditioning and ASHP equipment (Maguire et al. 2013).

Modeling by Larson et al. (2011) demonstrated similar impacts for the climate zones in the Pacific Northwest, with between 52 and $57 \%$ of water heater savings diminished by increased heating system energy use for an electric resistance furnace installed in conditioned space, as shown in Table 2.3. Accounting for the cooling system benefit reduced the net impact slightly, to between 46 and 52\% of the annual water heating energy savings.

Table 2.3. Comparison of Water Heating Energy Savings (kWh/yr) and HVAC System Interactions $(\mathrm{kWh} / \mathrm{yr})$, and Percentage Change in Net Energy Savings Due to HVAC System Interactions (\%). Source: Larson et al. 2011.

\begin{tabular}{lcccccc}
\hline $\begin{array}{c}\text { PNW } \\
\text { Climate } \\
\text { Zone }\end{array}$ & $\begin{array}{c}\text { Change } \\
\text { in Water } \\
\text { Heating } \\
\text { Energy } \\
\text { Use } \\
\text { HPWH }\end{array}$ & $\begin{array}{c}\text { Change in } \\
\text { Space } \\
\text { Heating } \\
\text { Energy Use } \\
\text { (Zonal } \\
\text { Resistance) }\end{array}$ & $\begin{array}{c}\text { Percent } \\
\text { Change in } \\
\text { Savings Due } \\
\text { to Heating } \\
\text { Penalty }\end{array}$ & $\begin{array}{c}\text { Change in } \\
\text { Space Cooling } \\
\text { Energy Use } \\
\text { (SEER 13 } \\
\text { ASHP) }\end{array}$ & $\begin{array}{c}\text { Percentage } \\
\text { Change in } \\
\text { Savings Due to } \\
\text { Cooling } \\
\text { Benefit }^{(a)}\end{array}$ & $\begin{array}{c}\text { Total Percent } \\
\text { Change in Net } \\
\text { Savings Due to } \\
\text { HVAC System } \\
\text { Interactions }^{\text {(a) }}\end{array}$ \\
\hline $\begin{array}{l}\text { Heating } \\
\text { Zone 1 }\end{array}$ & & 823 & $-52 \%$ & & & $-46 \%$ \\
$\begin{array}{l}\text { Heating } \\
\text { Zone 2 } \\
\text { Heating }\end{array}$ & -1578 & 845 & $-53 \%$ & -91 & $6 \%$ & $-48 \%$ \\
Zone 3 & 907 & $-57 \%$ & & $-52 \%$ \\
\hline \multicolumn{2}{l}{ (a) A positive change in water heating energy savings indicates increased savings (decreased energy use), while a negative } \\
\hline
\end{tabular}


change in water heater energy savings indicates decreased savings (increased use) as compared to the modeled water heater energy savings from the HPWH without accounting for the space conditioning impact.

(b) For regional energy analysis, the Pacific Northwest divides the region, which consists of Montana, Idaho, Washington, and Oregon, into three Heating Zones based on the different climates experienced in the region. See the Northwest Power and Conservation Council's Sixth Power Plan for more details. (Northwest Power and Conservation Council 2010; http://www.nwcouncil.org/media/6290/SixthPowerPlan_Appendices.pdf, pp. E-17 and E-18).

However, comparative field data are not available to verify modeling assumptions or modeled performance. 



\subsection{Experimental Protocol}

The purpose of this project is to evaluate the energy performance and DR characteristics of General Electric's (GE's) second-generation GeoSpring ${ }^{\mathrm{TM}}$ hybrid water heater in controlled experiments in PNNL's matched pair of Lab Homes. ${ }^{6}$ The research protocol consists of two primary experiments designed to measure the performance and impact on the Lab Home HVAC system during heating and cooling season periods of HPWHs in two pairs of configurations:

1. a GE GeoSpring HPWH configured with exhaust ducting compared to an unducted GeoSpring HPWH

2. a GeoSpring HPWH with both supply and exhaust air ducting as compared to an unducted GeoSpring HPWH

Both homes deployed identical simulated occupancy and hot water use schedules so that the performance and effects of the HPWHs can be isolated from all other variables. The following sections describe the key experimental resources and equipment, the research protocol, and the baselining procedure implemented to provide data quality and significance.

\subsection{GE Generation II GeoSpring Hybrid (Heat Pump) Water Heater}

HPWHs work by transferring heat from the ambient air to the water in the tank via a refrigeration cycle, similar to heat pumps that condition air. This process provides more energy to the water than it uses in electricity. Figure 3.1 shows the key components in a HPWH.

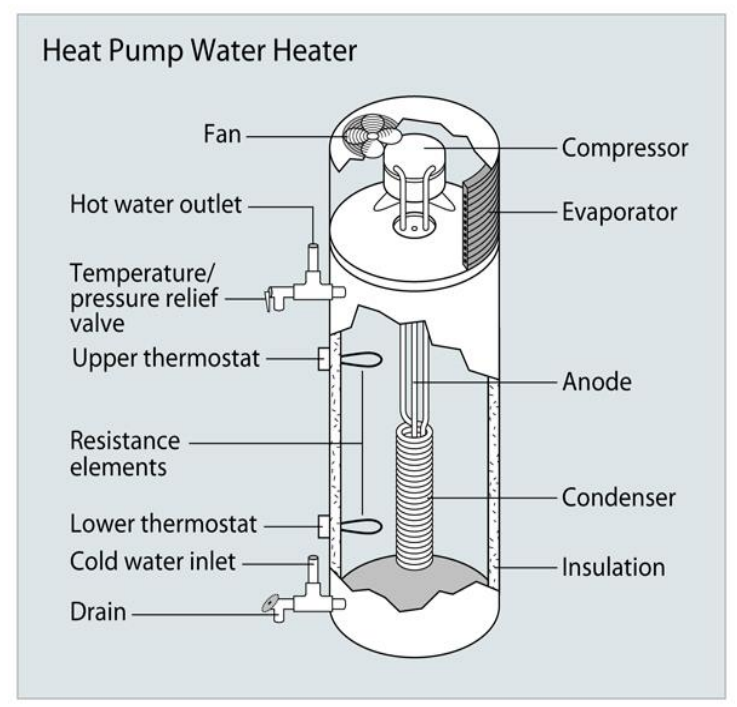

Figure 3.1. Diagram of Key Components in a Unitary HPWH. Source: U.S. DOE; energysavers.gov.

The HPWH selected for evaluation in this project is the second-generation GE GeoSpring Hybrid Water Heater (model GEH50DEEDSR), which is enabled with Brillion ${ }^{\mathrm{TM}}$ wireless communication and

\footnotetext{
${ }^{6}$ (http://labhomes.pnnl.gov)
} 
control technology. Two GE GeoSpring HPWHs were purchased for this project, both of which were manufactured in Louisville, Kentucky. The GE GeoSpring HPWH has a nominal 50-gallon tank and two methods of heating water: a highly efficient compressor and two 4500-watt (W) electric elements. The unit is equipped with onboard controls that dictate which heating mode is used to heat water. These modes consist of "Heat Pump," "Hybrid," "High Demand," "Standard," and "Vacation." The specific control strategies employed in each of these modes are explained in detail in documentation on the GE website (GE Appliances 2012) and have been evaluated in the laboratory by Larson and Logsdon (2012). The GE GeoSpring HPWH has a typical operating range between $100^{\circ} \mathrm{F}$ and $140^{\circ} \mathrm{F}$, although temperatures lower than $100^{\circ} \mathrm{F}$ are accessible in the "Vacation" setting.

For this experiment, the two GE GeoSpring water heaters were installed in the water heater closets in the conditioned spaces in Lab Home A and Lab Home B. The homes were modified by PNNL for this experiment as described in Section 3.3. Both HPWHs were operating in "Heat Pump" mode for all experimental periods, to maximize the impact on the space conditioning system.

\subsection{Monitoring Approach}

The monitoring approach included metering and system-control activities taking place at both the electrical panel and at the hot water end use. Monitoring was broken into electrical, air temperature, relative humidity, water temperature, and flow rate measurements. Table 3.1 highlights the performance metric (the equipment/system being monitored), the monitoring method and/or point, the monitored variables, the data application, and whether the monitoring existed in the Lab Homes or was newly installed and commissioned as part of this HPWH evaluation. All metering was done using Campbell® Scientific data loggers at 1-minute, 15-minute, and hourly intervals. Metering points in the PNNL Lab Homes not relevant to the HPWH experiments and further technical specifications on the controllable breaker panel, data acquisition system, and relevant sensors are described in detail in a previous report (Widder et al. 2012).

Table 3.1. Metering Strategy and Equipment

\begin{tabular}{llll}
\hline \multicolumn{1}{c}{ Monitored Parameter } & \multicolumn{1}{c}{$\begin{array}{c}\text { Monitoring } \\
\text { Method/Points }\end{array}$} & Monitored Variables & Data Application \\
\hline Electrical Power Measurements & & \\
\hline Whole-House Electrical & & Comparison and difference \\
Power and Circuit Level & 1 Campbell Scientific & calculations between homes of \\
Power & data acquisition system & $\mathrm{kW}$, amps, volts & -time-series power profiles \\
HPWH Electrical Power & and & -energy use differences and \\
Electric Power for HPWH & with 42 circuit & savings \\
Fan & transducers at electrical & & \\
Power for Electric Heaters & power mains and panel & & \\
Electric Power for Air & & &
\end{tabular}




\begin{tabular}{|c|c|c|c|}
\hline Monitored Parameter & $\begin{array}{c}\text { Monitoring } \\
\text { Method/Points } \\
\end{array}$ & Monitored Variables & Data Application \\
\hline \multicolumn{4}{|c|}{ Air Temperature and Humidity Measurements } \\
\hline Space Temperatures & $\begin{array}{l}13 \text { ceiling-hung } \\
\text { thermocouples/ } 1-2 \\
\text { sensors per room/area, } \\
\text { and } 1 \text { HVAC duct supply } \\
\text { temperature per home }\end{array}$ & Temp., ${ }^{\circ} \mathrm{F}$ & $\begin{array}{l}\text { Comparison and difference } \\
\text { calculations between homes of } \\
\text {-temperature profiles } \\
\text {-time-series temperature } \\
\text { changes }\end{array}$ \\
\hline $\begin{array}{l}\text { Space Relative Humidity } \\
\text { (RH) }\end{array}$ & $\begin{array}{l}2 \text { relative-humidity } \\
\text { sensors per home (main } \\
\text { living area, hall outside } \\
\text { of bathroom) }\end{array}$ & $\mathrm{RH}, \%$ & $\begin{array}{l}\text { Comparison and difference } \\
\text { calculations between homes of } \\
\text {-RH profiles and } \\
\text {-time-series RH changes }\end{array}$ \\
\hline $\begin{array}{l}\text { Water Heater Closet } \\
\text { Supply Air Temperature } \\
\text { and RH }\end{array}$ & $\begin{array}{l}\text { Thermocouple or } \\
\text { thermistor directly in } \\
\text { front of supply air grille } \\
\text { or in duct (if ducted) }\end{array}$ & Temp., ${ }^{\circ} \mathrm{F}$ & $\begin{array}{l}\text { Determine impact of supply } \\
\text { air temp on HPWH } \\
\text { performance }\end{array}$ \\
\hline $\begin{array}{l}\text { Return Air Temperature } \\
\text { and RH }\end{array}$ & $\begin{array}{l}\text { Thermocouple or } \\
\text { thermistor directly in } \\
\text { front of return air grille } \\
\text { or in duct (if ducted) }\end{array}$ & $\begin{array}{l}\text { Temp., }{ }^{\circ} \mathrm{F} \\
\mathrm{RH}, \%\end{array}$ & $\begin{array}{l}\text { Determine HPWH } \\
\text { temperature difference across } \\
\text { the coil and impact of exhaust } \\
\text { air temp on conditioned space }\end{array}$ \\
\hline $\begin{array}{l}\text { Water Heater Closet Air } \\
\text { Temperature and RH }\end{array}$ & $\begin{array}{l}\text { Four thermocouples } \\
\text { equally spaced } \\
\text { approximately } 2 \mathrm{ft} \text { apart } \\
\text { to capture the vertical } \\
\text { temperature gradient in } \\
\text { the water heater closet }\end{array}$ & Temp., ${ }^{\circ} \mathrm{F}$ & $\begin{array}{l}\text { Assess impact of HPWH on } \\
\text { water heater closet } \\
\text { temperature and determine } \\
\text { extent of stratification }\end{array}$ \\
\hline Crawlspace Temp & $\begin{array}{l}\text { Thermocouple(s) or } \\
\text { thermistor(s) to measure } \\
\text { temperature in at least } \\
\text { one location (near duct } \\
\text { inlet) and one at each } \\
\text { end (east and west) }\end{array}$ & Temp., ${ }^{\circ} \mathrm{F}$ & $\begin{array}{l}\text { Determine impact of } \\
\text { crawlspace air temp on } \\
\text { supply-ducted HPWH } \\
\text { performance }\end{array}$ \\
\hline $\begin{array}{l}\text { Meteorological } \\
\text { Measurements }\end{array}$ & $\begin{array}{l}\text { Package station mounted } \\
\text { on Lab Home B }\end{array}$ & $\begin{array}{l}\text { Temp., }{ }^{\circ} \mathrm{F} \\
\text { Humidity, } \% \\
\text { Wind speed, } \mathrm{m} / \mathrm{s} \\
\text { Wind direction } \\
\text { Barometric pressure, mm } \\
\text { Rainfall, inches }\end{array}$ & $\begin{array}{l}\text { Analytical application to } \\
\text { quantify setting and develop } \\
\text { routines for application to } \\
\text { other climate zones }\end{array}$ \\
\hline \multicolumn{4}{|c|}{ Water Temperature Measurements } \\
\hline Inlet Water Temperature & Insertion thermocouple & Temp., ${ }^{\circ} \mathrm{F}$ & $\begin{array}{l}\text { Characterize impact of } \\
\text { incoming water temperature } \\
\text { on HPWH performance }\end{array}$ \\
\hline Outlet Water Temperature & Insertion thermocouple & Temp., ${ }^{\circ} \mathrm{F}$ & $\begin{array}{l}\text { Monitor outlet water } \\
\text { temperature to determine } \\
\text { impact on delivered hot water }\end{array}$ \\
\hline Tank Temperature & $\begin{array}{l}\text { Thermocouple(s) near } \\
\text { tank on thermal cut-out } \\
\text { sensors }\end{array}$ & Temp., ${ }^{\circ} \mathrm{F}$ & Monitor tank temperatures \\
\hline \multicolumn{4}{|l|}{ Flow Rate Measurements } \\
\hline Outlet Water Flow Rate & $\begin{array}{l}\text { Turbine flow meter, in } \\
\text { line with hot water outlet } \\
\text { prior to mixing valve }\end{array}$ & Flow rate, gpm & $\begin{array}{l}\text { Verify water draws are in } \\
\text { accordance with specified } \\
\text { profile }\end{array}$ \\
\hline Exhaust Air Flow Rate & Exhaust fan flow meter & Flow rate, CFM & $\begin{array}{l}\text { Verify airflow rate to HPWH } \\
\text { in different duct } \\
\text { configurations }\end{array}$ \\
\hline
\end{tabular}




\subsubsection{Electrical Measurements}

In each home, all 42 of the panel electrical breakers were monitored for amperage and voltage. The resulting data were used to calculate apparent and real power $(\mathrm{kVA} / \mathrm{kW})$. All data were captured at 1-minute intervals by the data logger.

\subsubsection{Temperature and Environmental Sensors}

Space Temperature. Identical networks of temperature sensors are deployed in both homes. Each defined area of the home (individual rooms, hallway, and open living areas) has at least one thermocouple; a total of 17 space temperature thermocouples were installed per home. These include four thermocouples installed vertically spaced in the water heater closets to evaluate stratification within the closet. All temperature measurements were taken with Type $\mathrm{T}$ thermocouples at 1-minute intervals by the Campbell Scientific data logger.

Supply and Exhaust Air Temperatures. Type T thermocouples (two) were installed to measure supply and exhaust process air through the heat pump compressor. Three crawlspace temperature sensors monitoring the temperature of the crawlspace were also installed, which will be the temperature of the supply air when the HPWH is configured in the fully ducted arrangement. A diagram of the crawlspace temperature locations is shown in Figure 3.2.

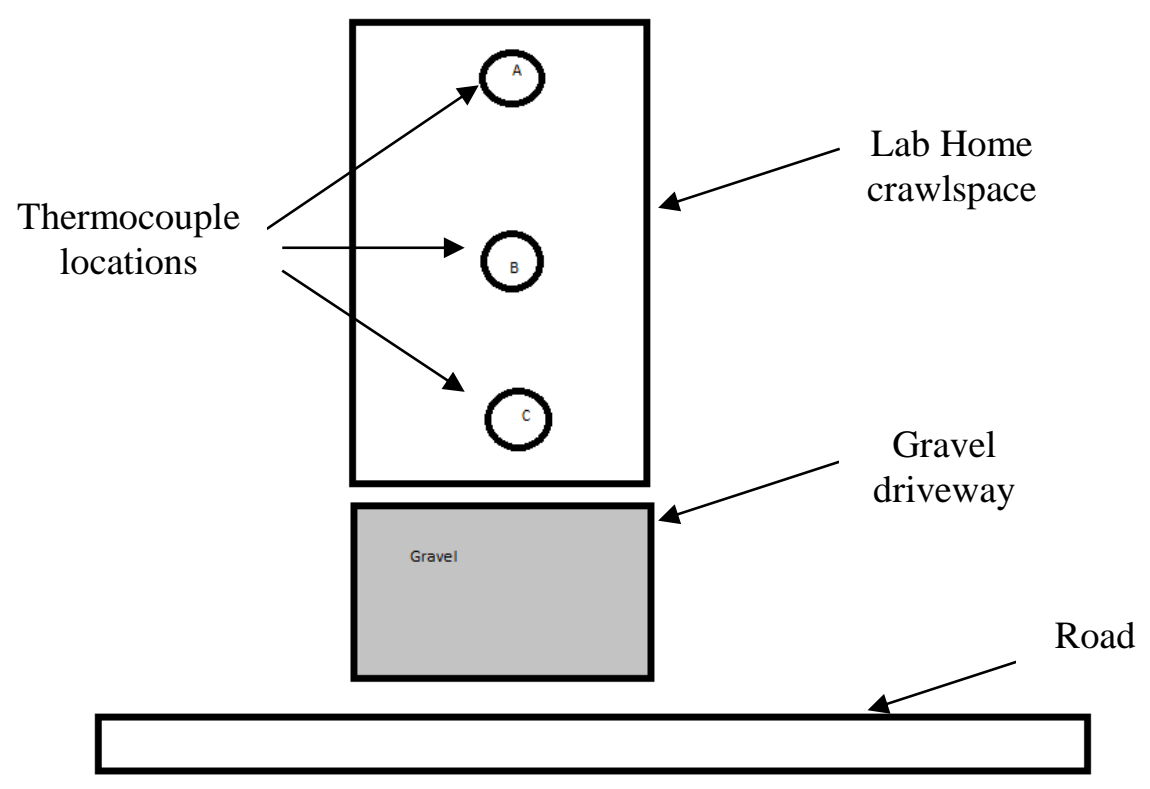

Figure 3.2. Crawlspace Thermocouple Locations (plan view)

Water Temperature. Water temperatures were recorded for the incoming water to the tank, the outgoing water delivered to the fixture, and for the tank at the high and low thermal cut-out sensors. All temperature measurements were taken with Type $\mathrm{T}$ thermocouples at 1-minute intervals by the Campbell Scientific data logger. 
Water Flow Rate. The water flow rate is measured using a low-flow impeller-type flow meter with 375 to 1380 pulses per gallon (0.07-5 gallon or 0.2-20 gallon range, depending on the model) with a 624 VDC output. This information is important to verify that the water draw schedule is identical in both homes and to verify overall draw volumes and rates. After installation, it was determined that the meters required field calibration. After field calibration, the flow meter in Lab Home A had a K-factor of 480 and that in Lab Home B had a K-factor of 1,371.

Relative Humidity. Two humidity sensors were installed in each home, one in the living area and one in the hallway. These data were collected and compared to verify that comparable humidity profiles were present in each home.

\subsubsection{Data Acquisition System}

All metering equipment, data loggers and indoor and outdoor sensors were installed and commissioned prior to initiating testing. Data from all sensors were collected via four data acquisition systems, one for environmental sensors and one for energy sensors in each home. Data were downloaded using Internet Protocol cellular modems. A polling computer, located in the metering lab on the PNNL campus, was connected to each logger using Campbell Scientific software. Data were recorded on 1-minute, 15-minute, and hourly intervals. One-minute data was used for all analysis to capture any short-duration changes in energy use within the home - for example, from a heating element cycling onand to limit error introduced from averaging over longer time periods. Data were averaged over hourly intervals for analysis. Calculated hourly averages were compared to the recorded hourly data as part of the data quality assurance process.

\subsection{HPWH Installation}

From December 2012 through February 2013, the Lab Homes were modified to each be equipped with a GE GeoSpring HPWH. The HPWHs were installed in the water heater closets in both homes, as shown in Figure 3.3. Installation of the HPWHs was in accordance with regional protocols developed by NEEA for the Northern Climate Specifications and the GE product installation instructions (NEEA 2013; GE Appliances 2014). 


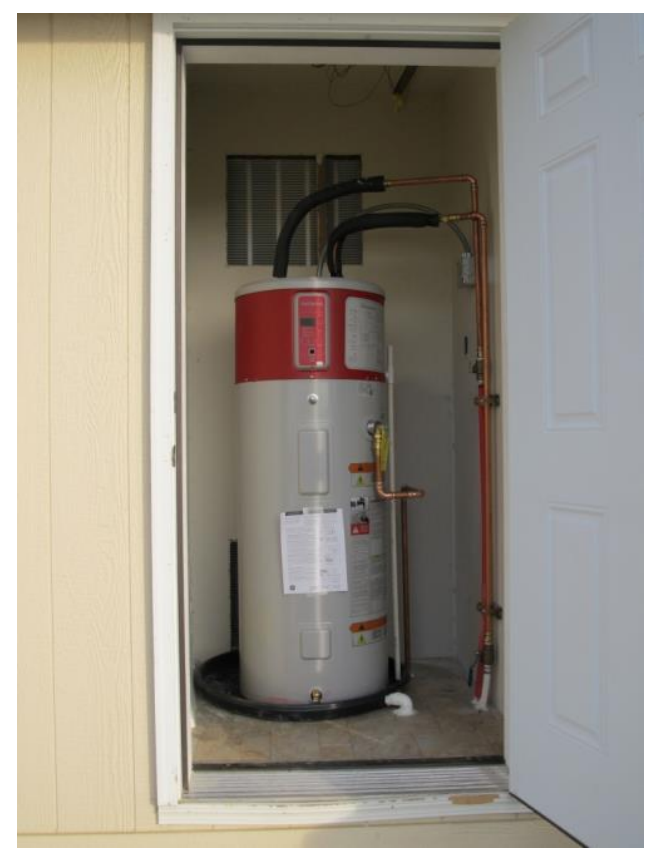

Figure 3.3. GE Gen-II GeoSpring HPWH Installed in Lab Home Water Heater Closet

The water heater closet was modified to allow free airflow with two pairs of 25 -inch $\times 20$-inch metal transfer grilles into the master bedroom closet (adjacent to the water heater closet) and the hallway (adjacent to the master bedroom closet), as indicated in Figure 3.4.
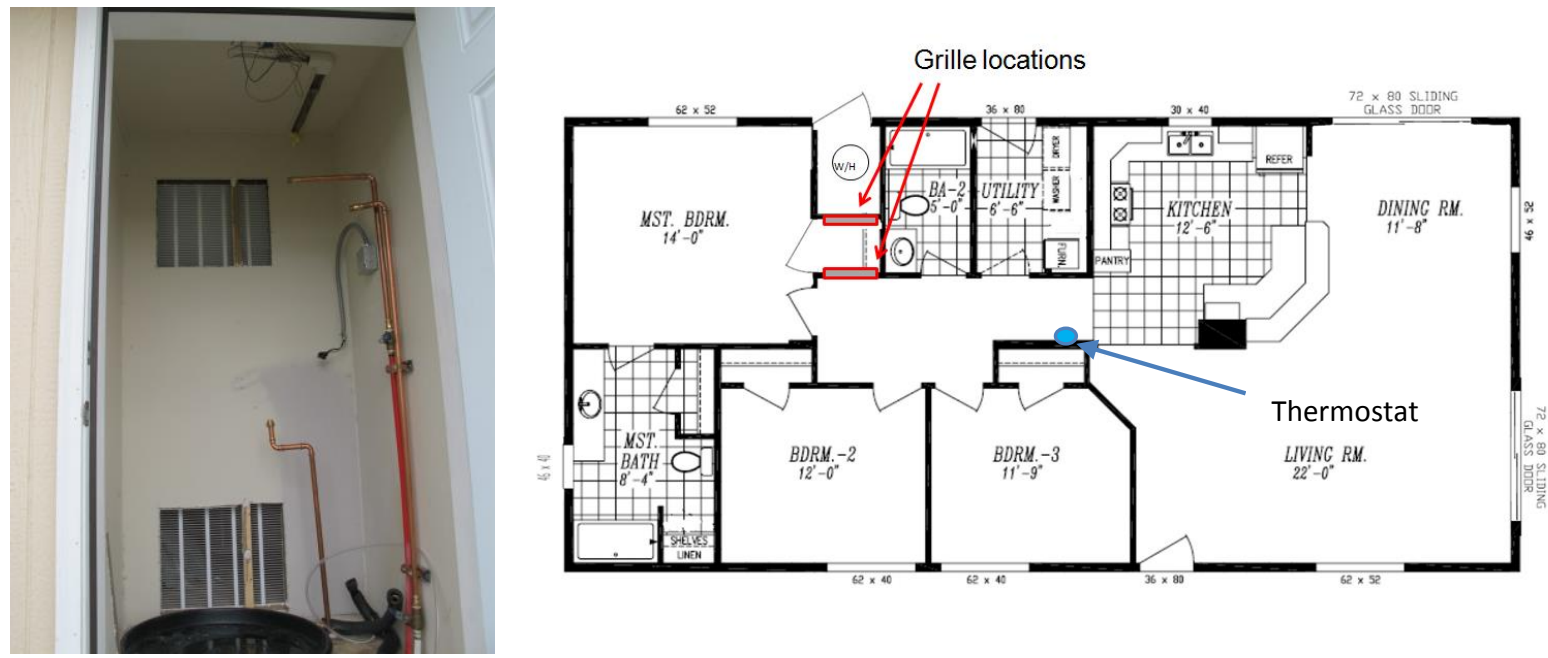

Figure 3.4. Transfer Grille and Thermostat Locations. Left: transfer grilles $(25$-inch $\times 20$-inch) installed between water heater closet and adjacent master bedroom closet. Right: location of grilles on wall 1) between water heater closet and master bedroom closet and 2) between master bedroom closet and hallway to provide sufficient free airflow to the water heater closet

One grille was installed low on the wall and one high, to help induce mixing. They were provisioned with magnetic covers to allow for blocking one of the airflow paths to study the impact of grille placement and size on HPWH performance. Each grille area is greater than $100 \%$ of the requirement specified in the GE product literature of 240 square inches (GE Appliances 2014). 
The water heater in Lab Home $\mathrm{A}^{7}$ was modified to accommodate supply and exhaust ducting. The ducting was designed to be easily connected and disconnected based on the experiment. The design for exhaust and supply ducting was developed in coordination with the project collaborators, including GE technical staff who reviewed the proposed approach. The exhaust ducting conforms to GE patent information on exhaust ducting for a GE HPWH (Nelson et al. 2012). Off-the-shelf duct components were used to construct a 6-inch diameter exhaust duct, which connects to a shroud designed to fit over the HPWH fan housing with the HPWH cover removed.

However, due to the location of the water heater closet exterior access door, the exhaust ducting had to be configured through the exterior access door to allow the door to remain operable. This required a longer, more circuitous exhaust ducting path. Because of the increased flow resistance caused by such configuration, and to overcome the additional static pressure requirements of drawing supply air, an inline $120-\mathrm{V}, 2$-speed exhaust fan was installed in the exhaust duct and wired to the HPWH compressor fan to operate only when the HPWH compressor fan is running. With 0.25 inches of static pressure, the fan is designed to deliver 163 cubic feet per minute (CFM) of air at the low-speed setting and 250 CFM of air at the high-speed setting. ${ }^{8}$

The supply ducting was a novel approach, with the airflow path drawing air from the crawlspace to the air intake on the top of the HPWH. A shroud was constructed that could be fastened to the top of the HPWH air intake, over the filter. An insulated 8-inch duct dropped straight down from the shroud to the water heater closet floor and penetrated through the floor to the crawlspace, as shown in Figure 3.5.

\footnotetext{
${ }^{7}$ The water heater in Lab Home B had no ducting capability. 8 Soler \& Palau. Mixed Flow Duct Fan, 8-3/8 In. L, Ball. Specifications are available through Grainger at: http://www.grainger.com/Grainger/SOLER-PALAU-Mixed-Flow-Duct-Fan-3CGA6
} 


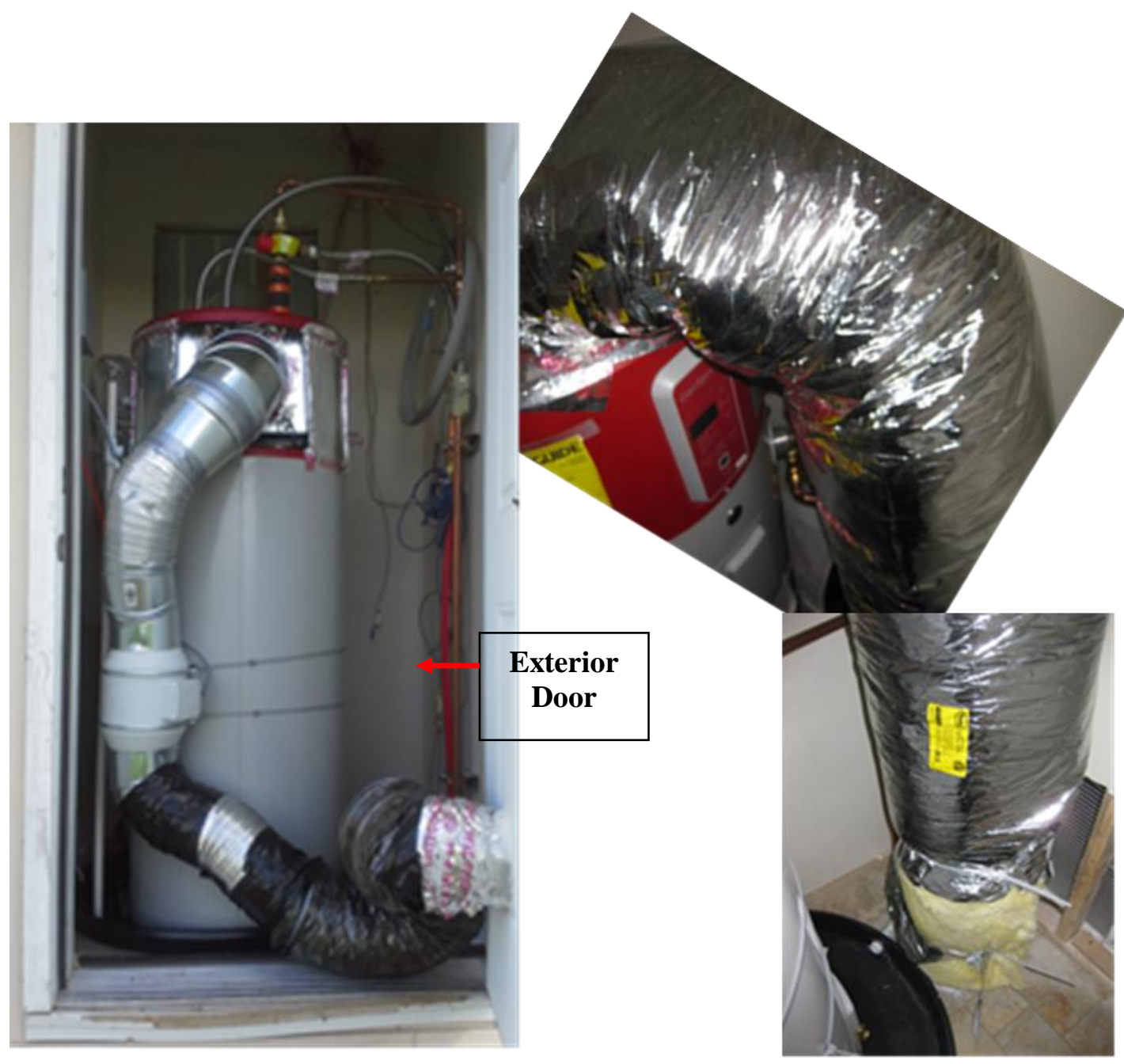

Figure 3.5. Left: Exhaust Ducting Approach on HPWH. Right: Supply Ducting Configuration on the HPWH

\subsection{Occupancy Simulation}

To simulate occupancy for the HPWH experiments, hot water draw profiles were implemented identically in both homes. The hot water draws used a modulating solenoid valve at the kitchen sink hot water supply and were controlled via the Campbell data acquisition system. Other occupancy loads in the homes were simulated via a programmable breaker panel (one per home) employing motorized breakers to simulate sensible loads associated with occupancy, lighting, and equipment and appliance loads. The simulated electrical loads and the selection of the hot water draw profile are described in the following section.

\subsubsection{Electrical Loads}

Controllable breakers were programmed to activate connected loads on schedules to simulate human occupancy. The bases for occupancy simulation were data and analysis developed in previous residential simulation activities (Hendron and Engebrecht 2010; Christian et al. 2010). The occupancy simulations 
and schedules developed here were derived specific to the home style, square footage, and an assumed occupancy of three adults. The per-person sensible heat generation and occupancy profiles were mapped from previous studies to be applicable to this demonstration. Occupancy and connected-lighting heat generation were simulated by activating portable and fixed lighting fixtures throughout the home. Each bedroom was equipped with a table lamp to simulate human occupancy; occupancy and lighting loads in other areas of the home were simulated via fixed lighting. Equipment loads were simulated identically in both homes using electric resistance wall heaters in the living/dining room: one $500 \mathrm{~W}$ and one 1,500 W heater ran simultaneously for a set number of minutes each hour. The occupancy simulation protocol was robustly commissioned and verified daily throughout the baselining and data collection periods. More detailed information on the electrical loads used to simulate occupancy and the relevant schedules is provided in Widder et al. (2013).

\subsubsection{Hot Water Draw Profile}

Water heater efficiency is dependent on hot water draw pattern, particularly draw volume and duration. However, the efficiency of tanked hot water heaters is more dependent on long water draws than that of tankless water heaters, which are more sensitive to short, frequent water draws. To select the hot water draw profile in the Lab Homes for the HPWH experiment, PNNL researched other draw profiles implemented by previous research, available standards, and data on typical field usage. The draw profile PNNL selected is described in this section and the full results of PNNL's analysis are presented in Widder et al. (2013).

Because the draw profile simulated in the Lab Homes needs to remain constant throughout the experiment to remove water draw profile as a variable from the comparison, choosing a draw pattern representative of aggregate average hot water use, such as the Building America House Simulation Protocol, seemed most appropriate.

PNNL selected a hot water draw profile that was representative of a typical daily draw pattern for a population of homes, rather than a single home, and that was feasible to implement reliably and consistently using existing equipment in the PNNL Lab Homes. PNNL selected the draw profile based on the Building America House Simulation Protocols, which specify typical daily draw volumes for different appliances based on the number of bedrooms, and an hourly draw pattern based on fraction of total daily load (Hendron and Engebrecht 2010). For a three-bedroom, two-bathroom Lab Home, the Building America House Simulation Protocol recommended a total hot water use of 78.51 gallons per day (gal/day), ${ }^{9}$ assuming a hot water tank temperature of $125^{\circ} \mathrm{F}$ and a delivered (mixed hot and cold) temperature of $110^{\circ} \mathrm{F}$ for showers, baths, and sinks, as shown in Table 3.2.

\footnotetext{
${ }^{9}$ Number of bedrooms $(\mathrm{Nbr})=3$ and number of office units (Nunit $=0$ )
} 
Table 3.2. Domestic Hot Water Heater Daily Use by End Use. Source: Hendron and Engebrecht 2010.

\begin{tabular}{|c|c|c|c|c|}
\hline End Use & $\begin{array}{c}\text { End-Use } \\
\text { Water } \\
\text { Temperature }\end{array}$ & Water Usage & $\begin{array}{l}\text { Sensible Heat } \\
\text { Gain }\end{array}$ & Latent Heat Gain \\
\hline Clothes washer & $\begin{array}{l}\text { Water heater } \\
\text { set point }\end{array}$ & 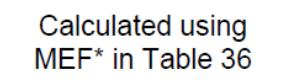 & $0^{*}$ & $0^{* *}$ \\
\hline Common laundry & $\begin{array}{l}\text { Water heater } \\
\text { set point }\end{array}$ & $\begin{array}{l}\text { Calculated using } \\
\text { MEF in Table } 36\end{array}$ & $0^{*}$ & $0^{* *}$ \\
\hline Dishwasher & $\begin{array}{l}\text { Water heater } \\
\text { set point }\end{array}$ & $\begin{array}{l}\text { Calculated using EF } \\
\text { in Table } 35\end{array}$ & $0^{* *}$ & $0^{* *}$ \\
\hline Shower & $110^{\circ} \mathrm{F}$ & $\begin{array}{c}14.0+4.67 \times \mathrm{N}_{\mathrm{br}} \\
\text { gal/day }\end{array}$ & $\begin{array}{c}741+247 \times \mathrm{N}_{\mathrm{br}} \\
\text { Btu/day }\end{array}$ & $\begin{array}{c}703+235 \times \mathrm{N}_{\mathrm{br}} \\
\text { Btu/day }(0.70+0.23 \\
\left.\times \mathrm{N}_{\mathrm{br}} \text { pints/day }\right)\end{array}$ \\
\hline Bath & $110^{\circ} \mathrm{F}$ & $\begin{array}{c}3.5+1.17 \times \mathrm{N}_{\mathrm{br}} \\
\text { gal } / \text { day }\end{array}$ & $\begin{array}{c}185+62 \times \mathrm{N}_{\mathrm{br}} \\
\text { Btu/day }\end{array}$ & $0^{* * *}$ \\
\hline Sinks & $110^{\circ} \mathrm{F}$ & $\begin{array}{c}12.5+4.16 \times \mathrm{N}_{\mathrm{br}} \\
\text { gal } / \text { day }\end{array}$ & $\begin{array}{c}310+103 \times \mathrm{N}_{\mathrm{br}} \\
\text { Btu/day }\end{array}$ & $\begin{array}{c}140+47 \times \mathrm{N}_{\mathrm{br}} \\
\text { Btu/day }(0.14+0.05 \\
\left.\times \mathrm{N}_{\mathrm{br}} \text { pints/day }\right)\end{array}$ \\
\hline Office/public sink & $110^{\circ} \mathrm{F}$ & $0.028 \times \mathrm{N}_{\text {units }}$ gal/day & $\begin{array}{c}0.69 \times \mathrm{N}_{\text {units }} \\
\text { Btu/day }\end{array}$ & $\begin{array}{c}0.314 \times \mathrm{N}_{\text {units }} \\
\text { Btu/day }\left(3.14 \times 10^{-4}\right. \\
\left.\times \mathrm{N}_{\text {units }} \text { pints/day }\right)\end{array}$ \\
\hline
\end{tabular}

PNNL determined the hot-only portion of the $110^{\circ} \mathrm{F}$ water draws based on an energy balance, to define the daily flow rate of $125^{\circ} \mathrm{F}$ water necessary to provide the stated volume of $110^{\circ} \mathrm{F}$ water at the tap.

A $125^{\circ} \mathrm{F}$ set point was selected based on the recent Lawrence Berkeley National Laboratory (LBNL) evaluation of field hot water use data, which found that $122.7^{\circ} \mathrm{F}$ was the average tank temperature (Lutz et al. 2011). The LBNL report also concluded that, based on the available field data, the majority of draws were between approximately 1 and 1.5 gpm and between 1 and 4 minutes in length (Lutz et al. 2011). The report also defined low, medium, and high daily hot water draws of 29.38, 60.52, and 98.04 gal/day, respectively.

For this comparison of HPWH performance under a number of different ducting scenarios, PNNL elected to simulate a "high" usage scenario and a profile similar to the Building America House Simulation Protocol. A high draw volume was chosen to create a worst-case scenario to evaluate the maximum space conditioning interaction. Thus, for the HPWH experiment, the daily hot water draw was adjusted by increasing the number of bedrooms in the Building America House Simulation Protocol calculations to five bedrooms, which results in hot water use of approximately $97 \mathrm{gal} /$ day at the $125^{\circ} \mathrm{F}$ set point. However, after significant effort calibrating the water control meters used in the homes, it was found that the valves used to restrict flow and provide a standardized flow rate were more accurate and precise at higher flow rates. Thus, the hot water flow rate was increased identically in each home from $1.5 \mathrm{gpm}$ to $2.0 \mathrm{gpm}$, for a total draw volume of $130 \mathrm{gal} / \mathrm{day}$. This draw profile exaggerates the HPWH/HVAC interaction, but was within the range of the daily hot water use data reported in the LBNL meta-analysis $^{10}$ (Lutz et al. 2011).

\footnotetext{
${ }^{10}$ The highest daily draw volume measured in the LBNL analysis was $163.21 \mathrm{gal} / \mathrm{day}$.
} 


\subsubsection{HVAC Operation}

Throughout the experiment, the HVAC systems were operated identically in the two homes. In the cooling season, the 2.5-ton SEER 13 heat pumps maintained an interior set point of $76^{\circ} \mathrm{F}$ with no setback, as per Building America House Simulation Protocols (Hendron and Engebrecht 2010). In the heating season, the heat pumps are set to "Emergency Heat," to operate like electric resistance furnaces and maintain an interior set point of $71^{\circ} \mathrm{F}$ with no setback (Hendron and Engebrecht 2010). Since heat pumps have a slightly nonlinear relationship to outdoor air temperature in that the COP of a heat pump changes with outdoor air temperature, precise calculation of space heating impacts would be difficult if operated in the heat pump mode. Electric resistance elements have an efficiency of $100 \%$, which makes measurement of space heating impacts more precise and accurate. In addition, the electric resistance furnace exaggerates the space conditioning impacts and represents the maximum heating system penalty that might be experienced in the field. The location of the thermostat in the Lab Homes is indicated in Figure 3.4, in the main body of the house (i.e., the central hallway) near the kitchen. 



\subsection{Results and Discussion}

The HPWHs, as installed in the PNNL Lab Homes, were baselined in March, April, and May 2013. Some difficulties were encountered maintaining equivalent water draws in both homes, resulting in a longer than expected baseline period. The cooling season data were collected between June and August 2013. Heating season performance data were collected in December 2013 and January 2014. In each season, the impact of exhaust ducting or both supply and exhaust ducting (i.e., full ducting) was evaluated on HPWH energy use, HVAC energy use, and interior temperatures. Both exhaust-only and full ducting were evaluated by modifying the GeoSpring HPWH in Lab Home A to be equipped with exhaust air ducting and full ducting, respectively, and comparing the performance to the performance of an unducted HPWH in Lab Home B.

The following sections present the experimental results for the baseline period and the impact of various ducting configurations on HVAC energy use, thermal comfort, water heater energy use, and whole-house energy use. Given the relative impact of ducting on whole-house energy use, the cost-effectiveness of installing ducting is also discussed.

\subsection{Baseline}

Prior to initiating the experiments, the homes were extensively baselined with the water heaters operating in electric resistance and heat pump modes. The baseline is essential to providing quality data, since any variability between the homes in the baseline would be retained and possibly magnified in the experimental phase, confounding any comparison of results between the homes. Fundamental home construction characteristics were verified as part of previous work and were not repeated here (Widder et al. 2012). However, due to the potential of changes in the homes, experimental blower door measurements were taken on both homes as part of the baseline period. Following blower door measurements, the homes went through an active null testing period, with full occupancy simulation to verify equivalent performance.

\subsubsection{Air Leakage}

Air leakage through the building shell was quantified in both homes using a Minneapolis Blower Door Model 3 and DG-700 digital pressure gauge in accordance with ASTM E779, Standard Test Method for Determining Air Leakage Rate by Fan Pressurization, and manufacturer recommendations (ASTM 2010; The Energy Conservatory 2012). The accuracy of the blower door is $3 \%$ of the reading, as stated in manufacturer's literature (The Energy Conservatory 2012).

Blower door tests were taken after modifications in both homes to accommodate the new HPWH equipment. It is important that both homes have similar air leakage, since the amount of air leakage will impact HVAC energy use in each home. Differences in air leakage will confound determination of the impact of ducting on whole-house energy use. The blower door results found both the baseline home and 
the experimental home to have test leakage rates of $0.18 \pm 0.01^{11}$ air changes per hour natural $\left(\mathrm{ACH}_{\mathrm{n}}\right)$ as shown in Table 4.1. These air exchange rates are statistically the same.

Table 4.1. Building Envelope Leakage as Measured by Blower Door Tests in the Baseline and Experimental Homes

\begin{tabular}{lcccc}
\hline & \multicolumn{2}{c}{ Lab Home A } & \multicolumn{2}{c}{ Lab Home B } \\
\cline { 2 - 5 } Parameter & Average Value & $\mathbf{\pm}$ Std. Dev. & Average Value & $\mathbf{\pm \text { Std. Dev. }}$ \\
\hline CFM50 & 783 & 4 & 824 & 4 \\
$\mathrm{ACH50}$ & 3.77 & 0.02 & 3.97 & 0.02 \\
$\mathrm{ACH}_{\mathrm{n}}{ }^{\text {(a) }}$ & 0.175 & 0.001 & 0.184 & 0.001 \\
\hline
\end{tabular}

(a) $\mathrm{n}=21.5$, based on single-story home in International Energy Conservation Code Climate Zone 3, minimal shielding

\subsubsection{Energy Comparison}

After instrumentation and the baseline assessments were completed in both Lab Homes, null testing was performed to compare energy use over several days prior to each of the cooling season and heating season experimental periods. Null testing with full occupancy (lighting, human-related, and equipment sensible loads) and simulated hot water draws showed similar energy use between the two homes, within $1.9 \pm 2.0 \%$ over the cooling season baseline testing period. During the cooling season null period, the homes were operated with the HVAC systems set to $75^{\circ} \mathrm{F}$ with no setbacks, in accordance with the Building America House Simulation Protocols (Hendron and Engebrecht 2010).

The differences in whole-house energy use between Lab Home A and Lab Home B were observed to be within $0.7 \pm 0.5 \%$ over the heating season baseline testing period. During the heating season null period, the homes were operated with the HVAC systems set as electric resistance furnaces and thermostat set points of $71^{\circ} \mathrm{F}$ with no setbacks, in accordance with the Building America House Simulation Protocols (Hendron and Engebrecht 2010) and the experimental conditions. Both the null testing periods for this experiment included operating the water heaters in heat pump mode, both without ducting, with a water heater tank set point of $125^{\circ} \mathrm{F}$.

Figure 4.1 shows a comparison of energy use between the experimental home (Lab Home A) and the baseline home (Lab Home B), for one day of the null test. The red 45-degree line indicates perfect agreement. This chart is representative of the agreement observed on the other days of null testing.

\footnotetext{
${ }^{11}$ All measured quantities are presented with their standard deviation to give a sense of variability of the measurements. Full statistical analysis was not performed as part of this report.
} 


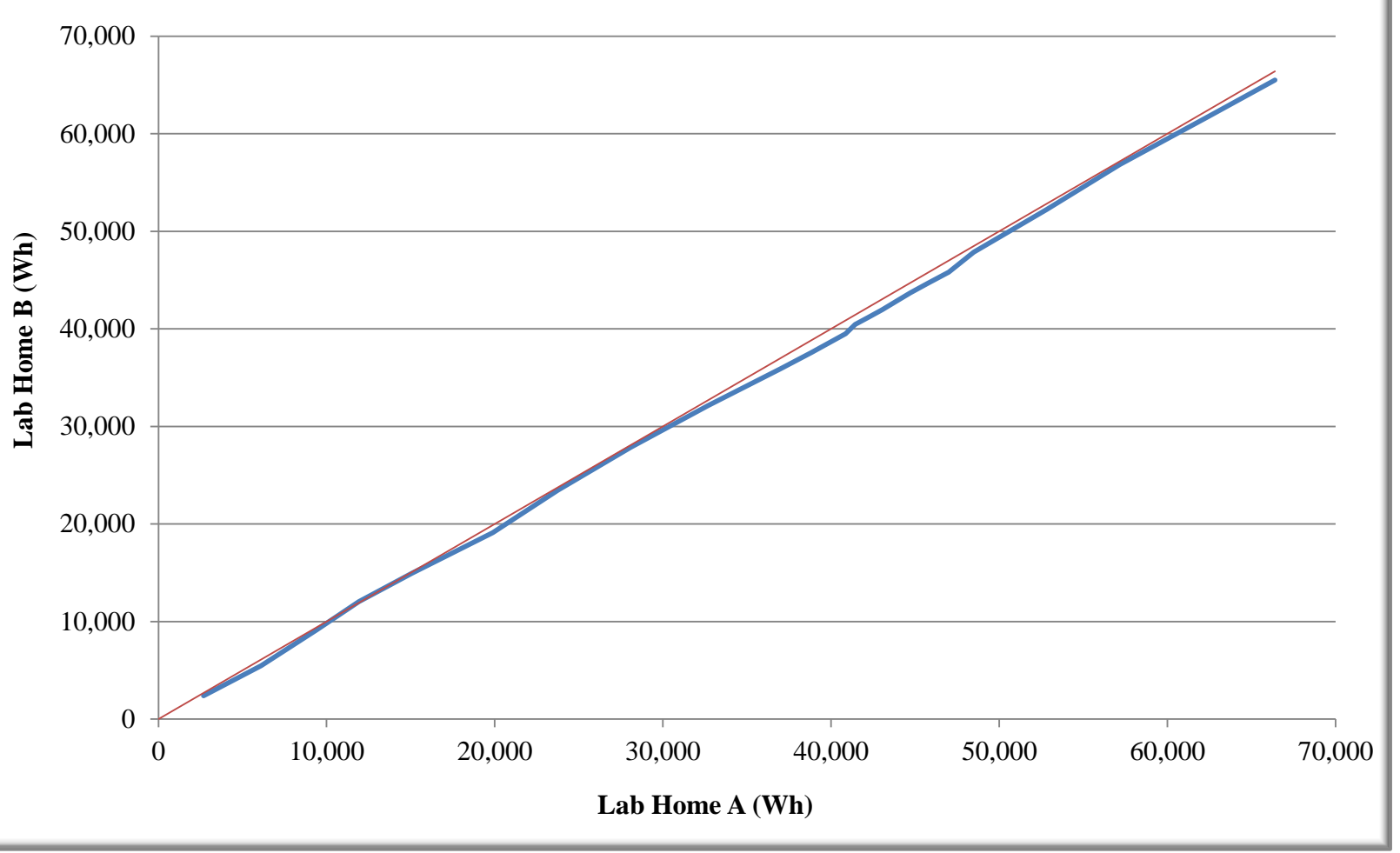

Figure 4.1. Comparison of Cumulative HVAC Energy Use of Lab Home A (x-axis) versus Lab Home B (y-axis)

Prior to initiation of the experiments, equivalent performance of water heaters in both homes was also verified for both electric resistance ("Standard" mode) and heat pump ("Heat Pump Only" mode) operation. The average hourly energy use for HPWH operation is nearly identical for the two homes, as exemplified in Figure 4.2. Other baseline days exhibited similar trends. The specific daily profiles and the electric resistance baseline information are presented in a previous report Widder et al. (2013). 


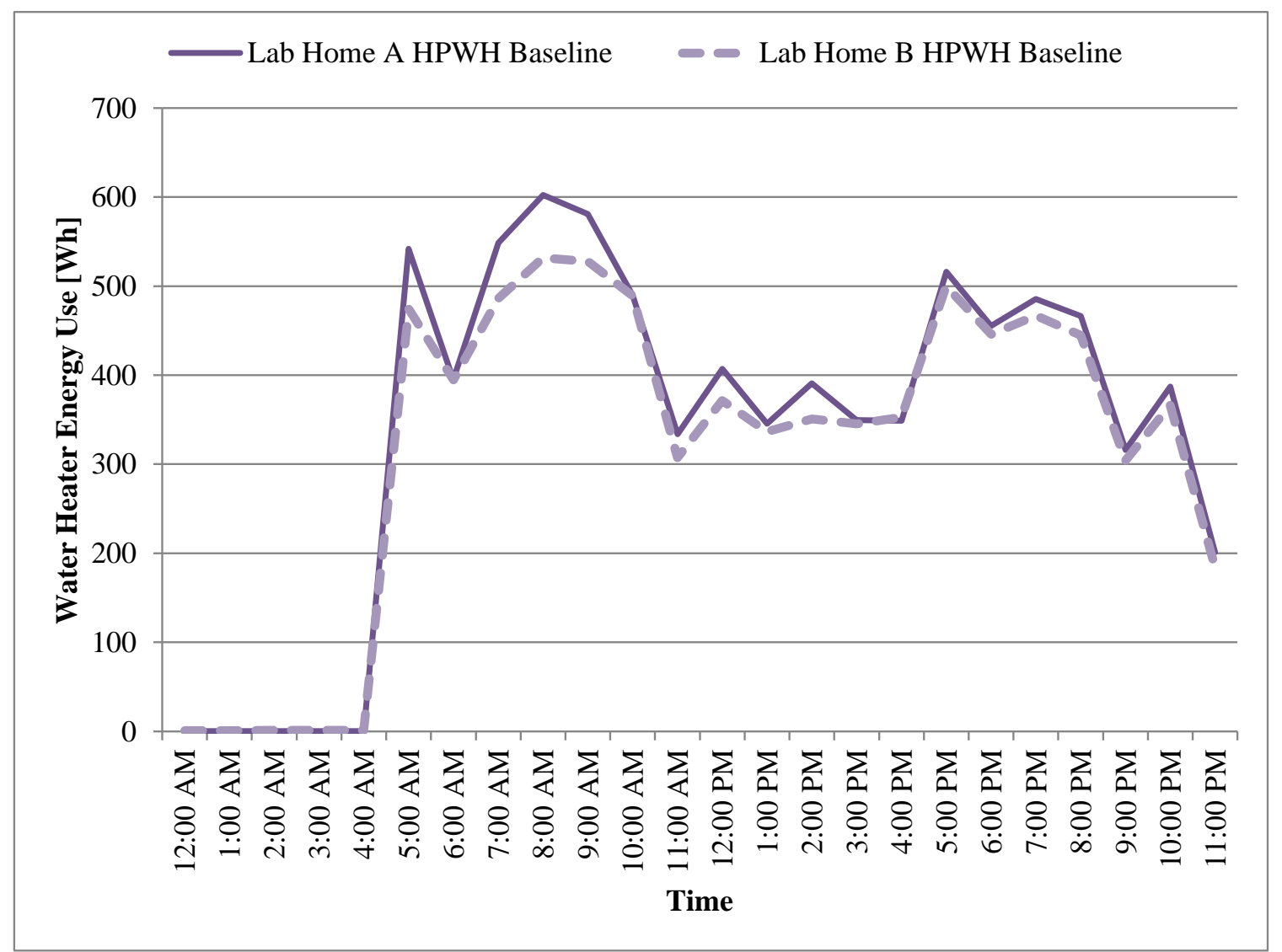

Figure 4.2. Average Daily Water Heater Energy Use Profile for Lab Home A and Lab Home B in Heat Pump Mode

Although the cooling season and heating season baseline periods confirmed similar performance of the two Lab Homes, any calculated differences in the whole-house, HVAC, and water heater energy use observed during the baseline period and associated variances are accounted for in the subsequent analysis of comparative water heater energy use and HVAC system interactions for the different ducting configurations.

\subsection{Impacts of Various Ducting Configurations on HVAC Energy Use}

Regarding space conditioning impacts, the heating season and the cooling season exhibited different trends, as one would expect.

\subsubsection{Cooling Season HVAC Energy Use Impacts}

In the cooling season, both exhaust-only and fully ducted scenarios led to increased HVAC energy usage as compared to the HVAC energy use with an unducted HPWH, since the supplemental space cooling from the HPWH exhaust cannot be taken advantage of in the ducted scenarios. The HPWH provides a space cooling benefit equivalent of approximately 1.5 kilowatt-hours per day $(\mathrm{kWh} /$ day $)$ in the unducted scenario. Since this additional space cooling is not available in the exhaust-only and fully ducted scenarios, these ducting configurations resulted in increased space conditioning energy use of 9.3 
$\pm 1.0 \%$ for the exhaust-only and $9.3 \pm 2.2 \%$ for the fully ducted scenario in the cooling season, as shown in Figure 4.3.

In Figure 4.3, HVAC energy use of Lab Home B with a HPWH in an unducted configuration is presented in blue; the HVAC energy use of the Lab Home A with a HPWH in an exhaust-only ducted configuration is presented in green; and the HVAC energy use of Lab Home A with a HPWH in a fully ducted configuration is presented in red. Note in each case, the duct treatment is compared directly to the corresponding unducted control case (Lab Home B). The average difference in HVAC energy use during each experimental period is represented by the yellow diamonds, where positive values indicate increased energy use resulting from ducting (Lab Home A - Lab Home B). The difference in the HVAC energy use in Lab Home B with the unducted HPWH between the exhaust-only ducted comparison and the fully ducted comparison periods is due to weather differences during the two experimental periods.

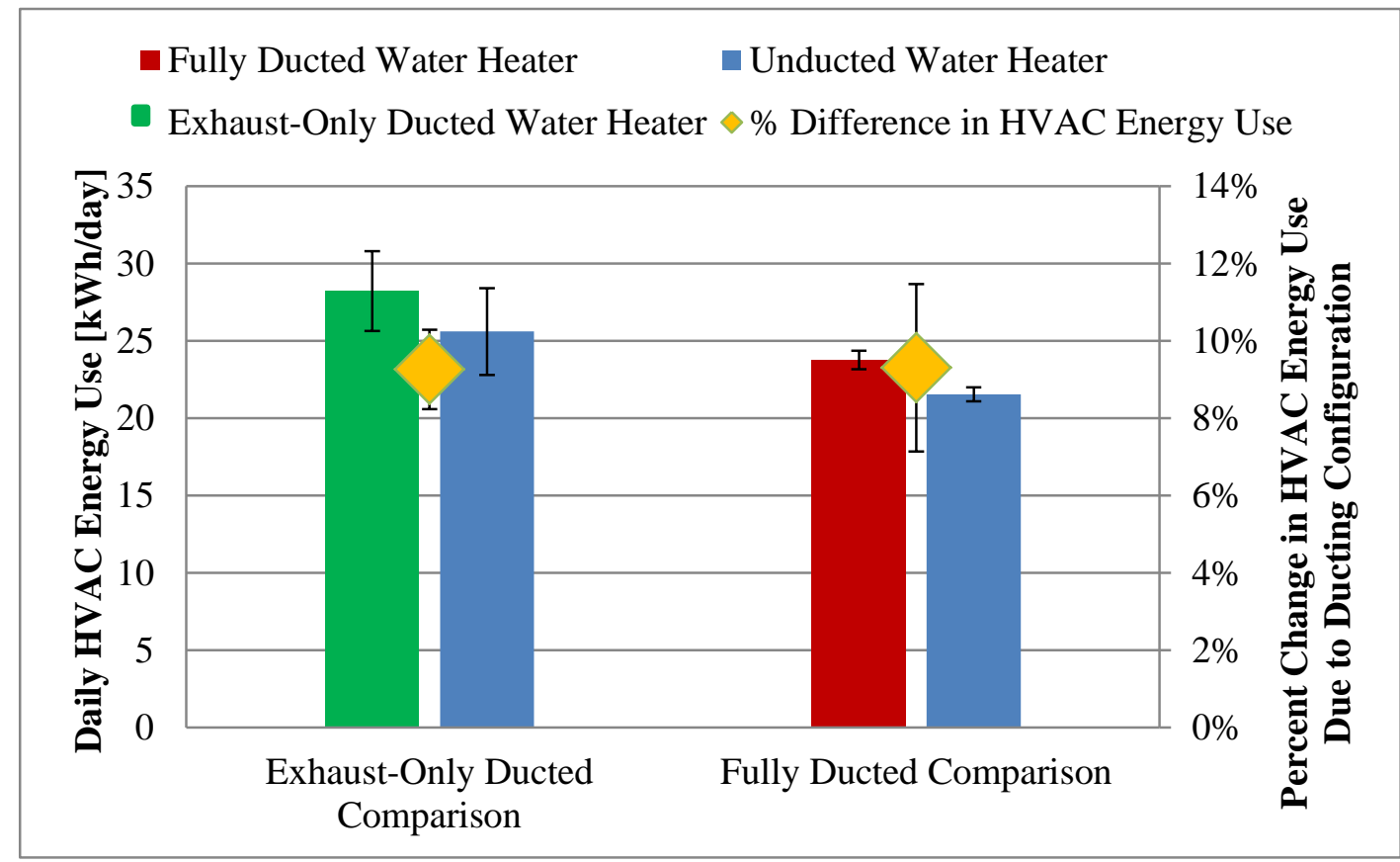

Figure 4.3. Daily HVAC Energy Use (kWh/day, left axis) and Difference in HVAC Energy Use (\%, right axis) for the Exhaust-Only Ducted Comparison and the Fully Ducted Comparison Periods in the Cooling Season

\subsubsection{Heating Season HVAC Energy Use Impacts}

In the heating season, HVAC energy use in Lab Home A in the exhaust-only ducted configuration increased as compared to the unducted HPWH in Lab Home B. Conversely, HVAC energy use in Lab Home A with the fully ducted HPWH decreased as compared to the unducted HPWH in Lab Home B, as shown in Figure 4.4. Figure 4.4 uses the same formatting as Figure 4.3. 


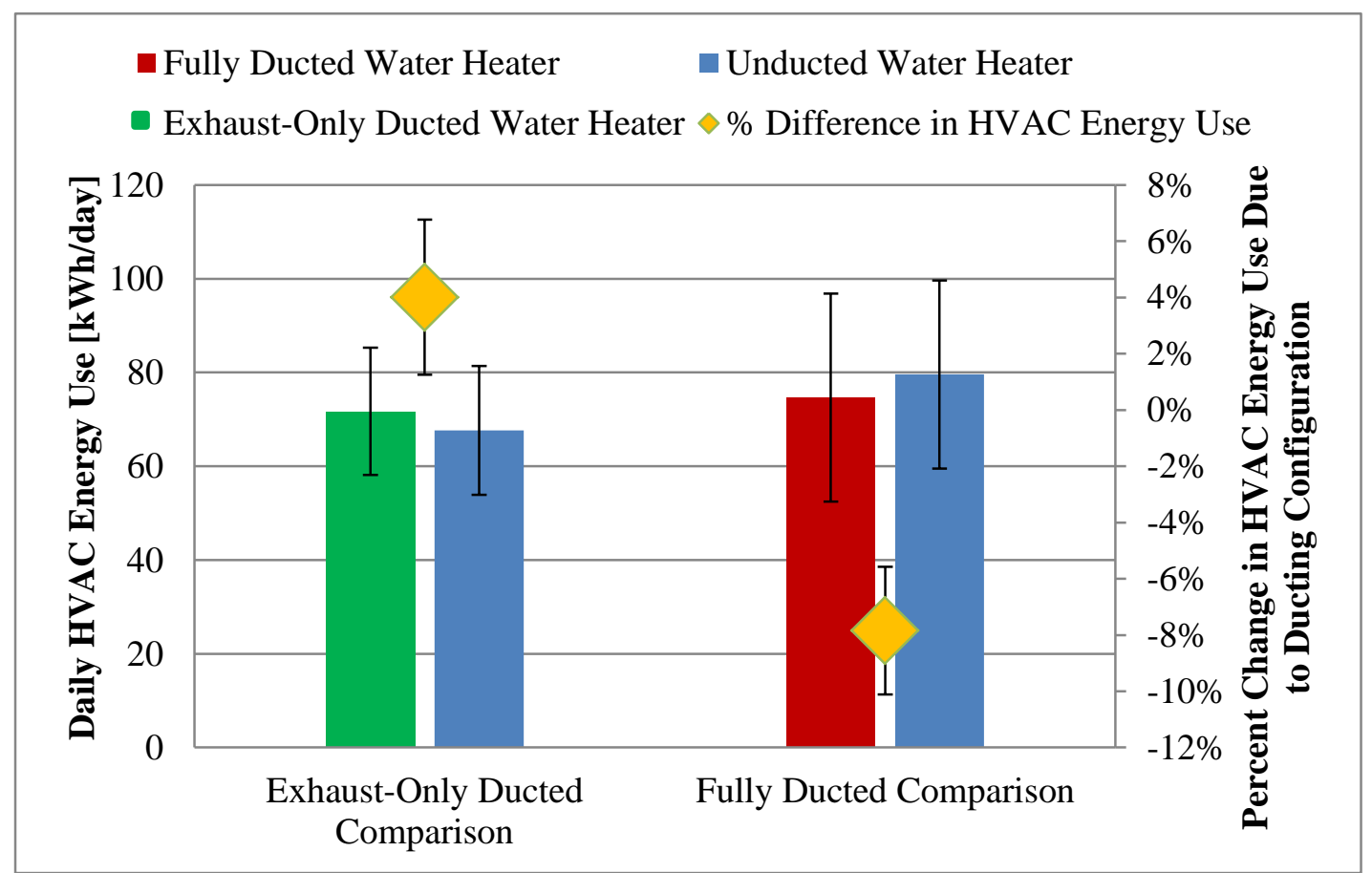

Figure 4.4. Daily HVAC Energy Use (kWh/day, left axis) and Difference in HVAC Energy Use (\%, right axis) for the Exhaust-Only Ducted Comparison and the Fully Ducted Comparison Periods in the Heating Season

For Lab Home A in the exhaust-only ducted configuration, the HVAC energy use increased $3.2 \pm 2.5$ $\mathrm{kWh} /$ day, or $4.0 \pm 2.8 \%$, which is converse to the expected impact of exhaust ducting. With regard to Lab Home A in the fully ducted configuration, the HVAC energy use was observed to decrease $7.8 \pm 2.3 \%$ as compared to Lab Home B with an unducted HPWH, reducing HVAC space conditioning loads by $5.7 \pm 1.6 \mathrm{kWh} /$ day.

Models have suggested that HPWHs installed in conditioned space will increase HVAC energy use in the heating season due to the use of air that has been initially heated by the HVAC system to heat water and the introduction of cool exhaust air into the space (Larson et al. 2011; Larson et al. 2012; Maguire et al. 2013). Therefore, models assume, any heat that has been extracted from the space must be made up, or reheated, by the HVAC system in order to maintain interior thermostat set points. These models also have shown that exhaust ducting will mitigate the impact of HPWHs on space conditioning systems by preventing cool exhaust air from being introduced into the conditioned space (Larson et al. 2011; Larson et al. 2012; Maguire et al. 2013). However, the data collected in this experiment suggest that exhaustonly ducting did not decrease space conditioning energy use, as compared to Lab Home B with an unducted HPWH.

It is hypothesized that the exhaust-only ducting did not help mitigate cold air exhaust into the home for two reasons. First, exhaust-only ducting may depressurize the conditioned space with respect to the outside, increasing infiltration and thus resulting in increased HVAC energy use to heat the outside air. In addition, the outdoor air introduced through infiltration was colder than the HPWH exhaust air temperature by, on average, $20^{\circ} \mathrm{F}$. Therefore, in the exhaust-only ducting case, the HVAC system had to make up more than twice the thermal energy removed by the space to heat the water. The doubling in thermal penalty associated with exhaust ducting is calculated based on a ratio of: (a) difference between 
the average daily outdoor air temperature and the interior thermostat set point and (b) the difference between the HPWH exhaust and the interior thermostat set point, as shown in Equation 7:

$$
\text { Relative Increase in Thermal Load on Space }=\frac{\left(T_{\text {in,air }}-T_{O A T}\right)}{\left(T_{\text {in, air }}-T_{\text {exhaust }}\right)}
$$

where

$$
\begin{aligned}
\mathrm{T}_{\text {in,air }}= & \text { the average interior temperature (or the thermostat set point) in }{ }^{\circ} \mathrm{F} \text {, as previously } \\
& \text { defined } \\
\mathrm{T}_{\text {OAT }}= & \text { the average outdoor air temperature in }{ }^{\circ} \mathrm{F} \\
\mathrm{T}_{\text {exhaust }}= & \text { the average temperature of the HPWH exhaust in }{ }^{\circ} \mathrm{F}
\end{aligned}
$$

During the heating season exhaust-only ducting experiment, the average outdoor air temperature was $34.2 \pm 4.2^{\circ} \mathrm{F}$, while the average HPWH exhaust air temperature was $54.5 \pm 3.1^{\circ} \mathrm{F}$ and the average interior temperature was $71.8 \pm 1.5^{\circ} \mathrm{F}$.

Full ducting, where the HPWH is completely isolated from the conditioned space and the HPWH does not impact the pressurization of the home with respect to the outdoors, showed a decrease in HVAC energy use during the heating season. This suggests that depressurization of the interior space and its resultant impacts on infiltration-related space conditioning energy use may be a significant factor when determining the space conditioning interaction with HPWHs, especially in cold climates where the outdoor air temperature is below the exhaust temperature of the HPWH for considerable portions of the year.

Second, the impact of an unducted HPWH on space conditioning loads may not be as large as models suggest. Specifically, many models assume a single, well-mixed zone such that any heat transferred to the water by the HPWH must be $100 \%$ made up by the HVAC system to return to the same thermal condition in the conditioned space. However, these experiments suggest that the relative amount of energy that must be made up by the HVAC system is less than $100 \%$. The increased space conditioning energy use resulting from the unducted HPWH in conditioned space is determined based on the difference in HVAC energy use between Lab Home A in the fully ducted configuration and Lab Home B with the unducted HPWH. Assuming that the fully ducted scenario perfectly cancels the effects of using air heated by the HVAC system and exhausting cool air into the conditioned space, the experimental data show that approximately $43.4 \pm 12.2 \%$ of the expected thermal energy contribution from the conditioned space is made up by the HVAC system in the heating season and approximately $37.2 \pm 4.7 \%$ is made up in the cooling season. The relative HVAC thermal load as compared to the theoretical thermal energy contribution from the conditioned space can be seen by comparing the orange and blue bars on the righthand side of Figure 4.5. Specifically, the average difference in HVAC thermal load with a fully ducted water heater in the heating season (orange bar on the far right) is approximately $43 \%$ of the theoretical thermal energy provided from the conditioned space during the heating season (orange bar second from the right). Similarly, the blue bar on the far right represents the average measured difference in HVAC thermal load with a fully ducted water heater and is approximately $37 \%$ of the theoretical thermal energy provided by the space to heat water (blue bar second from the right). 


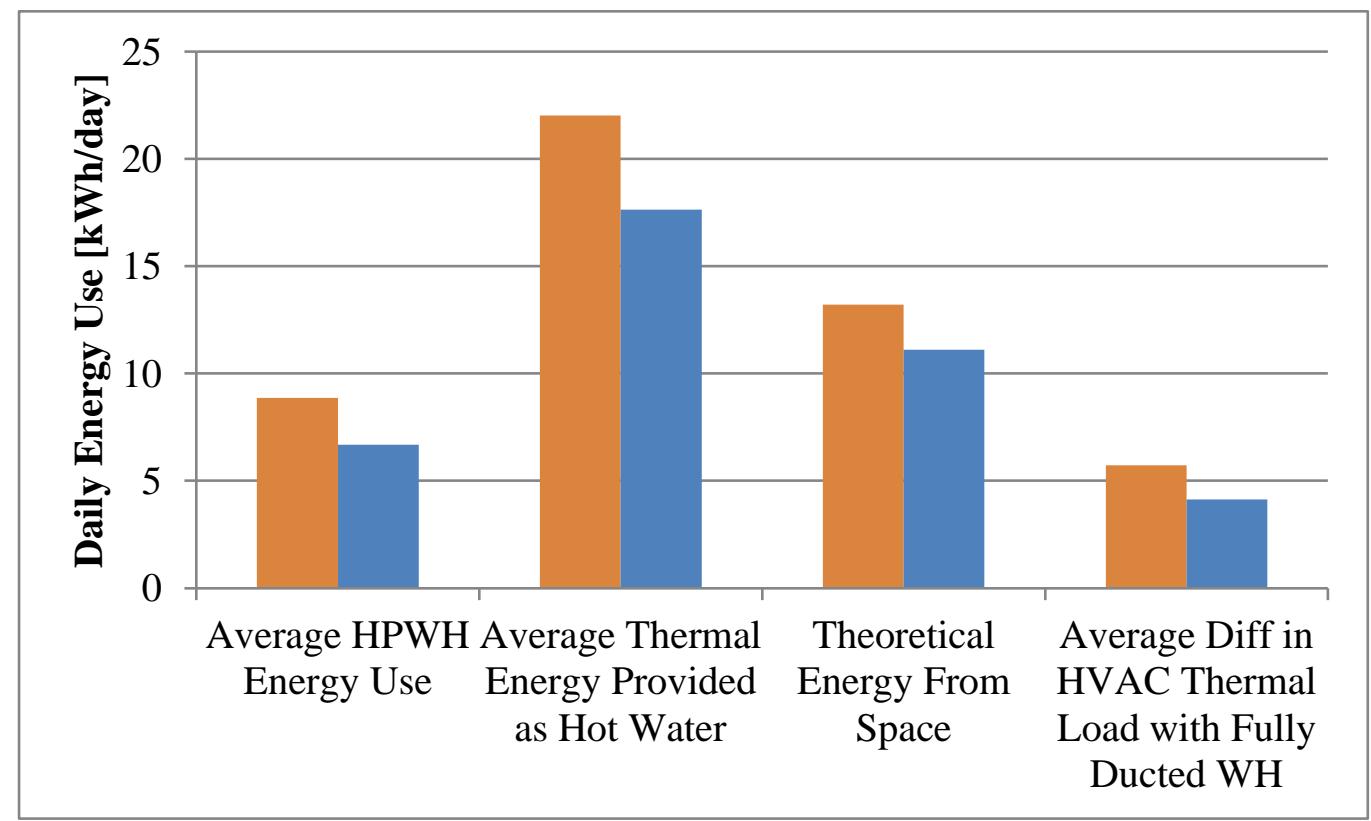

Figure 4.5. Comparisons in the Heating Season (orange) and Cooling Season (blue) of (a) Average HPWH Energy Usage (as electricity provided to the HPWH), (b) Average Daily Thermal Energy Provided as Hot Water, (c) Average Theoretical Contribution to Hot Water Thermal Energy Provided by the Space (determined based on the difference between (a) and (b)), and (d) the Average Difference in Daily HVAC Energy Use in Lab Home B with an Unducted HPWH Compared to Lab Home A with a Fully Ducted HPWH

On the far left side of Figure 4.5, the average daily HPWH energy usages observed for the unducted HPWH in the heating season (orange) and cooling season (blue) are depicted. In the cooling season, the HPWH consumes less energy than in the heating season due to higher mains temperatures and warmer interior temperatures. Second from the left, the thermal energy provided as hot water is shown, determined in accordance with Equation 2. This calculation was verified by comparing the resultant value to that calculated based on the measured HPWH electrical energy use and system COP, as discussed in Section 2.0 and presented in Equation 4. When comparing the two methods for calculating total thermal energy provided as hot water (Equations 2 and 4), the values agreed within 2\%. Third from the left, the theoretical energy provided by the space is presented for the heating season (orange) and the cooling season (blue). This is calculated as a simple difference between the average thermal energy provided as hot water (second bars from left) and the average HPWH electrical energy consumption (first bars on the left) for the heating season and cooling season, respectively. Note that this assumes $100 \%$ of the energy used to heat water that is not provided by electricity to the HPWH directly comes from the conditioned space.

The theoretical thermal loads on the conditioned space in the heating and cooling seasons were then compared to the average difference in HVAC thermal load measured during the experiments. Recall that the average difference in HVAC usage is calculated as a difference between the unducted and fully ducted cases, assuming the ducting perfectly isolates the HPWH from the space. Moreover, the bars on the far right present the average "thermal load," not the average HVAC electricity consumption during that period. This is particularly important for the cooling season experiment, where the measured difference in HVAC energy consumption during the fully ducted comparison, $1.3 \pm 0.5 \mathrm{kWh} / \mathrm{day}$, is scaled by the COP of the ASHP to determine the true thermal load on the space and account for the efficiency of the 
HVAC system. The COP of the ASHP installed in the Lab Homes was determined based on the rated SEER of the equipment (SEER 13) and was assumed to be constant over the analysis period. This assumption will introduce some inaccuracies into the calculation, but should not change the general trends observed; also, full COP performance maps for the ASHPs installed in the Lab Homes are not readily available. For the heating season, such a conversion is not necessary, since the efficiency of the electric resistance furnace is $100 \%$. Also note that the "average difference in HVAC thermal load with fully ducted WH" represents an increase in HVAC energy use for the HPWH without ducting in the heating season (Lab Home B - Lab Home A) and a decrease in HVAC energy use associated with the unducted HPWH in the cooling season (Lab Home A - Lab Home B).

The experimental data may suggest that the reduced HVAC impact is due to buffering of the HPWH space conditioning impacts by the interior walls. For the unducted HPWH, the water heater closet experienced localized cooling while the thermostat, located in the hallway near the kitchen (see Figure 3.4), did not experience the full effect of the HPWH thermal loads. The interior temperature data are discussed more fully in Section 4.3.

\subsection{Impacts on Thermal Comfort}

Due to the cold exhaust air expelled by a HPWH operating in conditioned space, some believe that HPWHs could cause localized cooling and lead to comfort concerns for homeowners (Kresta 2012). In addition, localized cooling can also impact the efficiency of the HPWH, since lower ambient air temperatures will lead to decreased heat pump performance.

In the case of the Lab Homes experiment, localized cooling was observed in the small closet where the water heater was located. As shown in Table 4.2, the temperatures in the water heater closet were affected by $5.4 \pm 5.5^{\circ} \mathrm{F}$ and $4.7 \pm 5.9^{\circ} \mathrm{F}$ in the exhaust-only and fully ducted cases in the cooling season and $8.0 \pm 4.1^{\circ} \mathrm{F}$ and $7.1 \pm 5.4^{\circ} \mathrm{F}$ in the heating season.

Table 4.2. Average and Standard Deviation of the Water Heater Closet Temperature in the Heating and Cooling Seasons for the Exhaust-Only Ducted and Fully Ducted Comparisons, in ${ }^{\circ} \mathrm{F}$

\begin{tabular}{ccccccc}
\hline & \multicolumn{2}{c}{ Exhaust-Only Ducted Comparison } & \multicolumn{2}{c}{ Fully Ducted Comparison } \\
\hline Cooling Season & Exhaust-Only & Unducted & Difference & Fully Ducted & Unducted & Difference \\
\hline $\begin{array}{c}\text { Water Heater Closet } \\
\text { Temperature }\left({ }^{\circ} \mathrm{F}\right)\end{array}$ & $73.7 \pm 1.2$ & $68.3 \pm 5.4$ & $5.4 \pm 5.5$ & $72.4 \pm 1.2$ & $67.9 \pm 5.3$ & $4.5 \pm 5.4$ \\
$\begin{array}{c}\text { Heating Season } \\
\text { Exhaust-Only }\end{array}$ & Unducted & Difference & Fully Ducted & Unducted & Difference \\
$\begin{array}{c}\text { Wer Heater Closet } \\
\text { Temperature }\left({ }^{\circ} \mathrm{F}\right)\end{array}$ & $64.3 \pm 2.6$ & $56.3 \pm 3.1$ & $8.0 \pm 4.1$ & $64.4 \pm 2.0$ & $56.0 \pm 2.7$ & $8.4 \pm 3.4$ \\
\hline
\end{tabular}

Note that the water heater closet temperatures are also quite variable, with standard deviations of around $5^{\circ} \mathrm{F}$ in all cases. This is because the closet is only cooled when the HPWH is operating and returns to near the temperature of the body of the house during extended periods of little or no water draw. For example, Figure 4.6 depicts the impact of exhaust ducting or full ducting, versus an unducted HPWH, on the water heater closet temperature. The average closet temperature with ducting (lighter blue in the third pane) is observed to be warmer than that with the unducted HPWH (darker blue in the third pane), and resembles the water closet temperature profile of an ERWH (lighter blue in the second pane). 


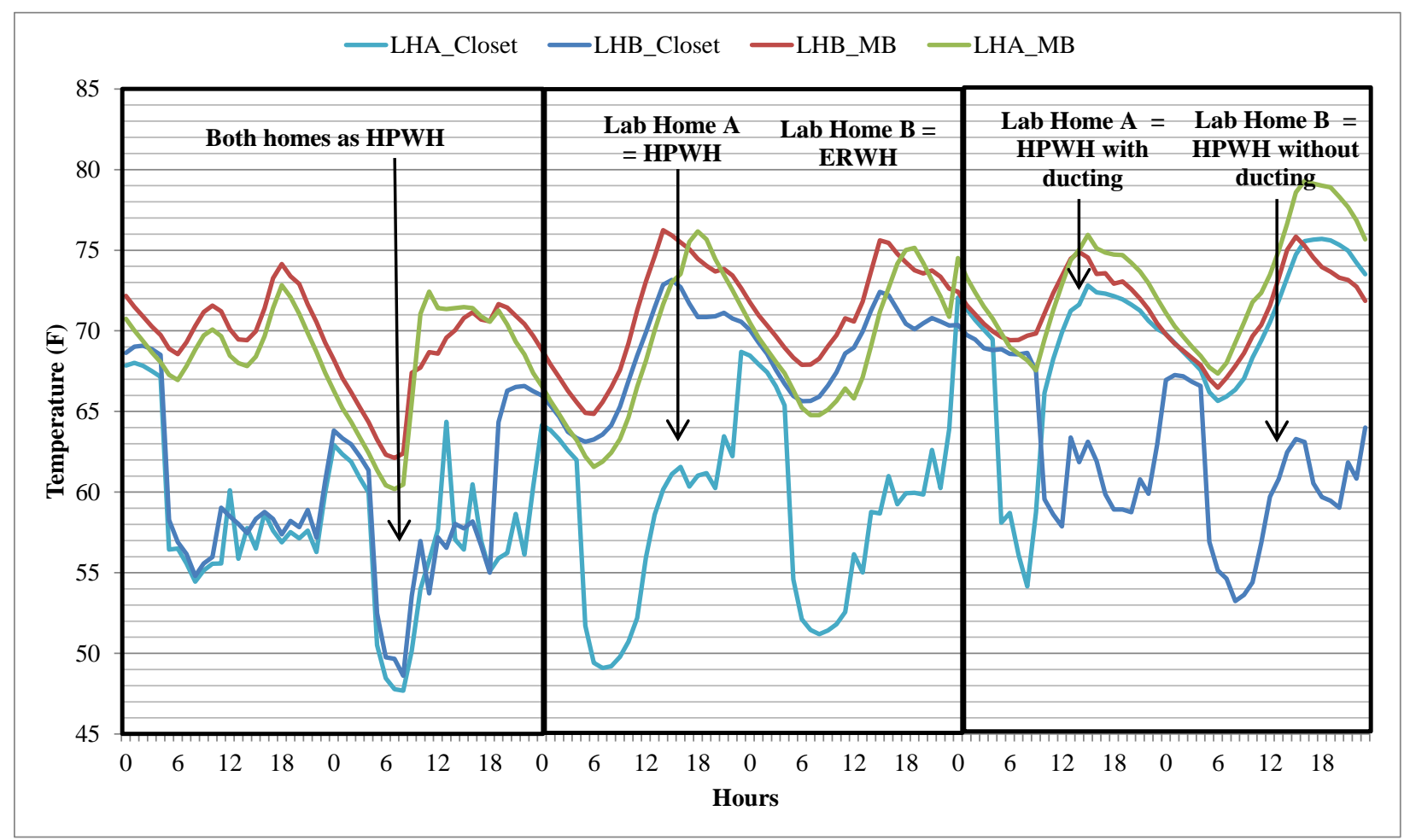

Figure 4.6. Water Heater Closet (_Closet) and Master Bedroom (_MB) Interior Temperatures for Lab Home A (LHA) and Lab Home B (LHB) for Six Days. Left: baseline operation with both water heaters operating as HPWHs; Center: Lab Home A as a HPWH and Lab Home B as an ERWH; Right: Lab Home A as a HPWH with ducting and Lab Home B as a HPWH without ducting

Due to the small size of the water heater closet and the fact that cold air was being blown into the space when the HPWH was operating, limited stratification of approximately $1-2^{\circ} \mathrm{F}$ was observed within the water heater closet in the cooling season. In the heating season, the observed stratification was more extreme (as high as $6-8^{\circ} \mathrm{F}$ ) in both the ducted and unducted cases. This may be caused by the cold outdoor air temperature and increased stack effect, which draws cold air in from the exterior door on the water heater closet. While the closet door is insulated and weather-stripped, it is not perfectly airtight and is a source of air infiltration.

However, the impact of different ducting configurations on the temperatures in other spaces in both homes was not significant. As shown in Table 4.3, the average interior temperatures observed in Lab Home A and Lab Home B during the exhaust-only ducted and fully ducted comparison periods were nearly identical, varying by less than $1^{\circ} \mathrm{F}$ in both the heating season and the cooling season. Although more than sufficient free area was available through the installation of grates in one wall of the water heater closet, the surrounding room temperatures were not impacted by HPWH exhaust, which suggests that the water heater closet experienced localized cooling while the remaining body of the house was affected less. 
Table 4.3. Average and Standard Deviation of Interior Temperatures Measured in the Main Body of the House and the HPWH Closet Temperature in the Heating Season and Cooling Season for the Exhaust-Only Ducted and Fully Ducted Comparisons, in ${ }^{\circ} \mathrm{F}$

\begin{tabular}{c|c|c|c|c|c|c}
\hline & \multicolumn{3}{|c|}{ Exhaust-Only Ducted Comparison } & \multicolumn{3}{c}{ Fully Ducted Comparison } \\
\hline Cooling Season & Exhaust-Only & Unducted & Difference & Fully Ducted & Unducted & Difference \\
$\begin{array}{c}\text { Average Interior } \\
\text { Temperature }\left({ }^{\circ} \mathrm{F}\right)\end{array}$ & $75.9 \pm 2.1$ & $75.5 \pm 2.3$ & $0.3 \pm 3.1$ & $74.7 \pm 0.4$ & $74.9 \pm 0.6$ & $-0.2 \pm 0.7$ \\
$\begin{array}{c}\text { Heating Season } \\
\text { Average Interior } \\
\text { Temperature }\left({ }^{\circ} \mathrm{F}\right)\end{array}$ & Exhaust-Only & Unducted & Difference & Fully Ducted & Unducted & Difference \\
\hline
\end{tabular}

While the installation of ducting did not appear to have a measurable impact on average interior temperatures in the main body of the house, some small temperature deviations were observed. In the cooling season, the master bedroom and master bathroom experienced slightly lower temperatures in Lab Home B with an unducted HPWH, as compared to Lab Home A with an exhaust-only or fully ducted $\mathrm{HPWH}$, as shown in Figure 4.7 and Figure 4.8. The master bedroom was $1.5 \pm 0.7^{\circ} \mathrm{F}$ cooler and the master bathroom was $2.8 \pm 0.6^{\circ} \mathrm{F}$ cooler in the unducted case than the exhaust-only ducted case, and $1.1 \pm 0.6^{\circ} \mathrm{F}$ and $1.6 \pm 0.3^{\circ} \mathrm{F}$ cooler in the fully ducted case, for the master bedroom and master bathroom, respectively. Since the master bedroom is adjacent to the water heater closet, the HPWH exhaust may have been cooling the master bedroom slightly. The master bathroom, however, is not near the water heater closet and the difference observed in the master bathroom is not as likely to be caused by the unducted HPWH.

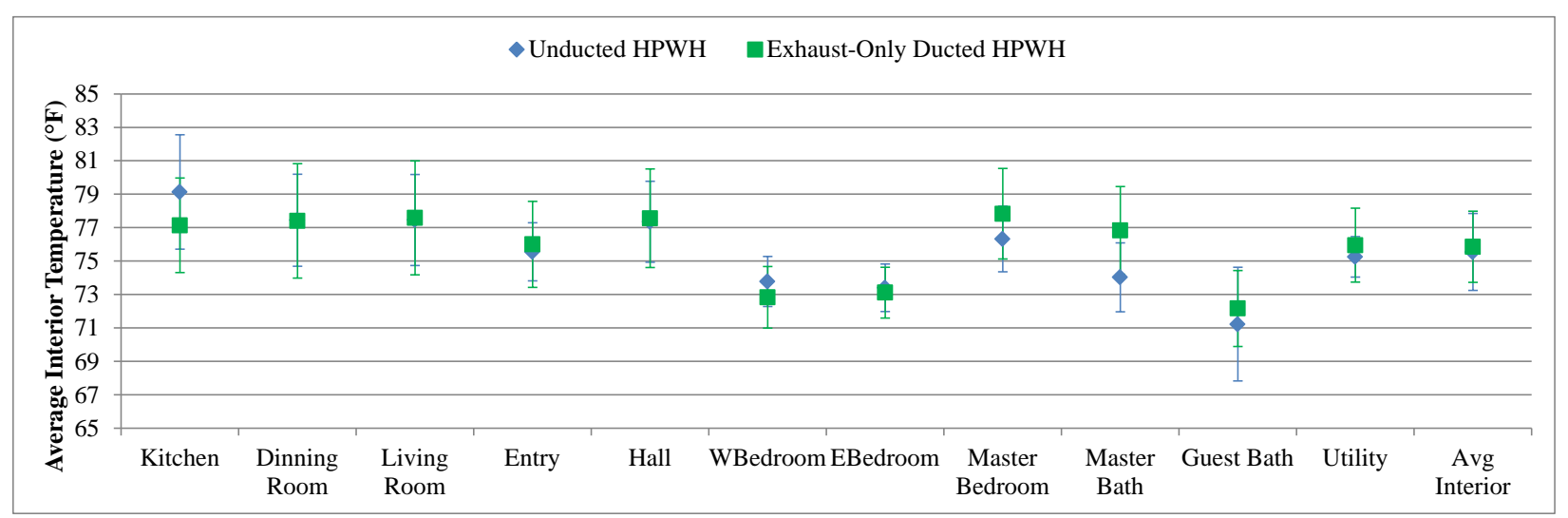

Figure 4.7. Average Temperature and Standard Deviation, in ${ }^{\circ} \mathrm{F}$, in Each Room During the ExhaustOnly Ducted Comparison Period in the Cooling Season 


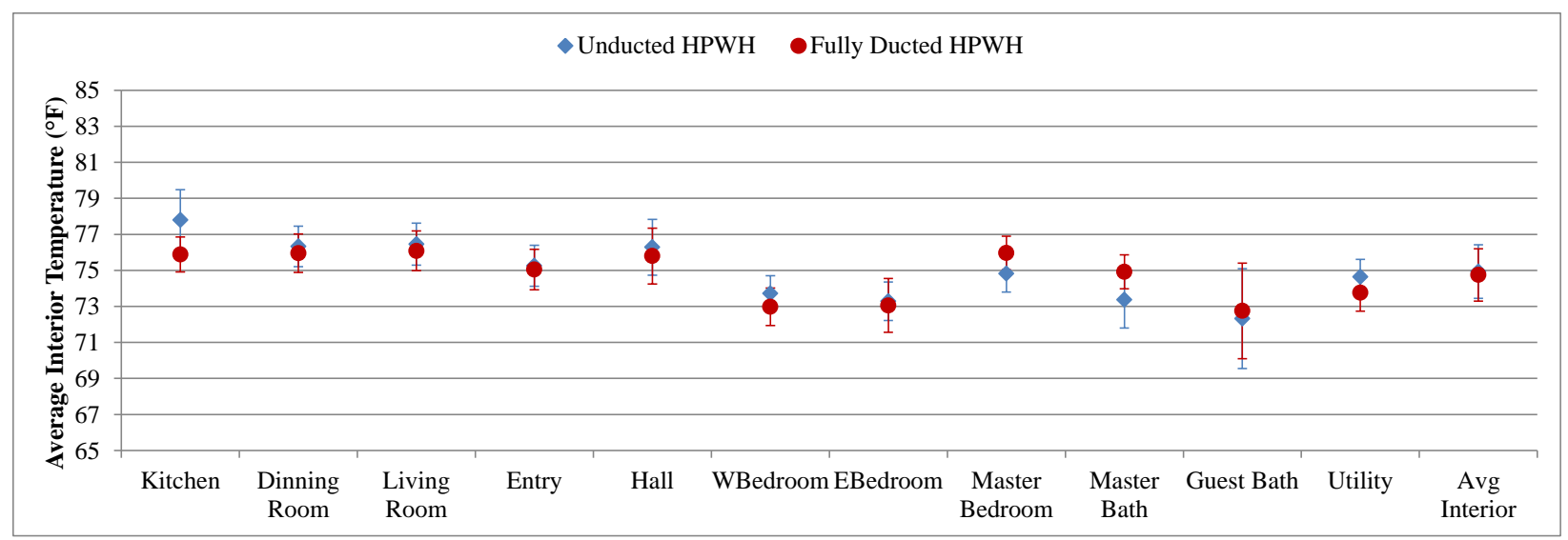

Figure 4.8. Average Temperature and Standard Deviation, in ${ }^{\circ} \mathrm{F}$, in Each Room During the Fully Ducted Comparison Period in the Cooling Season

In addition, the kitchen experienced slightly elevated temperatures in the unducted HPWH case, during both the exhaust-only and fully ducted HPWH comparison periods, by $1.9 \pm 1.0^{\circ} \mathrm{F}$ and $2.0 \pm 0.6^{\circ} \mathrm{F}$, respectively.

In the heating season, the largest temperature differentials were observed in the east bedroom and the master bathroom. The east bedroom in Lab Home $\mathrm{B}$ was, on average, $1.9 \pm 0.4^{\circ} \mathrm{F}$ and $1.5 \pm 0.4^{\circ} \mathrm{F}$ cooler than that in Lab Home A when equipped with exhaust ducting or full ducting, respectively. Conversely, the master bath demonstrated warmer temperatures in Lab Home B as compared to Lab Home A when equipped with exhaust ducting or full ducting, $1.5 \pm 0.4^{\circ} \mathrm{F}$ and $1.7 \pm 0.6^{\circ} \mathrm{F}$, respectively. The variances in the east bedroom and master bath, and the similar temperatures observed in the other rooms, are depicted in Figure 4.9 and Figure 4.10.

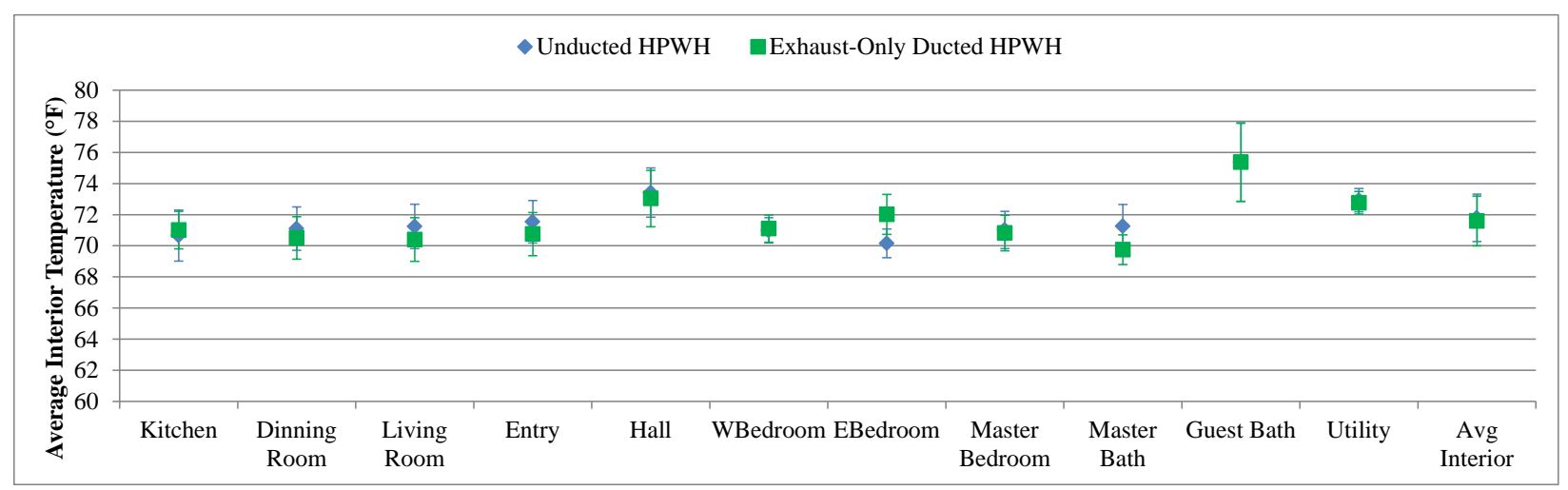

Figure 4.9. Average Temperature and Standard Deviation, in ${ }^{\circ} \mathrm{F}$, in Each Room During the ExhaustOnly Ducted Comparison Period in the Heating Season 


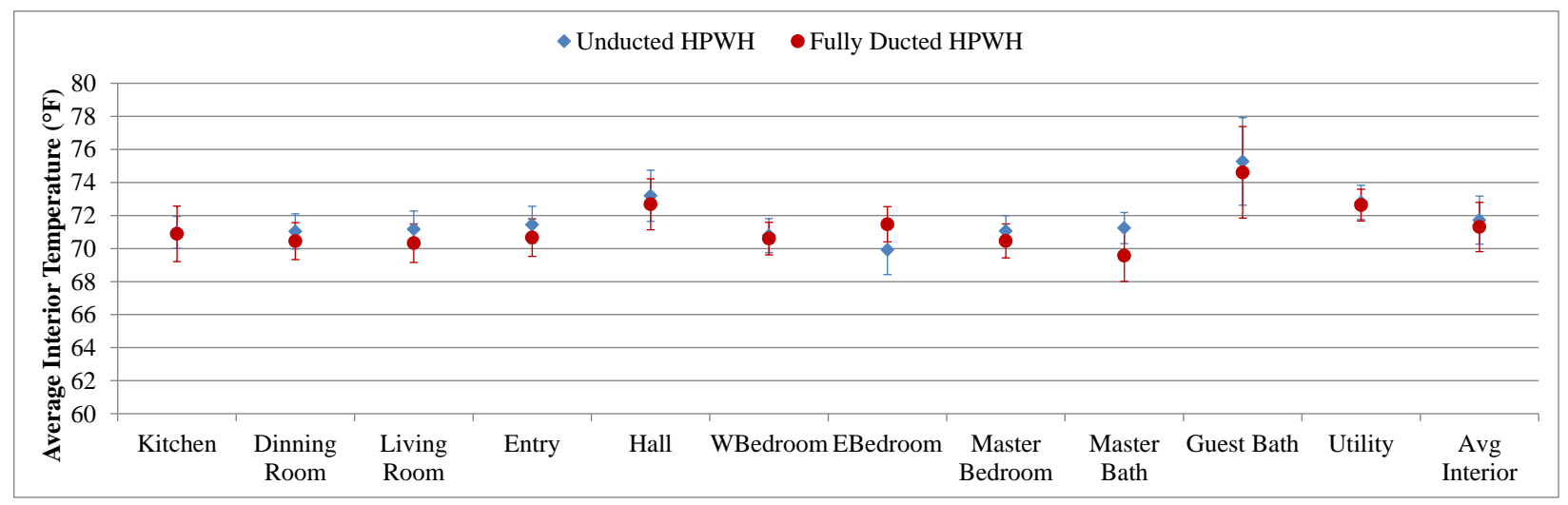

Figure 4.10. Average Temperature and Standard Deviation, in ${ }^{\circ} \mathrm{F}$, in Each Room During the Fully Ducted Comparison Period in the Heating Season

These $1-2^{\circ} \mathrm{F}$ deviations in temperature from Lab Home A to Lab Home B are not completely explained and further investigation is needed to explore whether the impacts are directly caused by the HPWH and ducting configuration or other factors. However, regardless of the cause, a $1-2^{\circ} \mathrm{F}$ change in temperature is not likely to significantly impact occupant comfort.

\subsection{Water Heating Energy Use}

Ducting can also impact the energy consumed by the water heater itself, as the efficiency of the HPWH will be affected by the temperature of the inlet air. For example, while the unducted water heater may provide space conditioning benefits in the cooling season, such a configuration may increase water heating energy use because the colder inlet air decreases HPWH efficiency. In the cooling season, both exhaust-only ducted and fully ducted configurations (Lab Home A) led to decreased water heater energy usage, $8.3 \pm 0.7 \%$ and $8.4 \pm 0.5 \%$ respectively, as shown in Figure 4.11, due to the ducting effectively mitigating localized cooling in the water heater closet. In the cooling season, crawlspace temperatures were not substantially different from interior temperatures due to ground coupling and shading. The crawlspace experienced an average temperature of $73.0 \pm 1.3^{\circ} \mathrm{F}$ and the interior conditioned space observed an average temperature of $74.7 \pm 0.4^{\circ} \mathrm{F}$ during the fully ducted comparison period in the cooling season. 


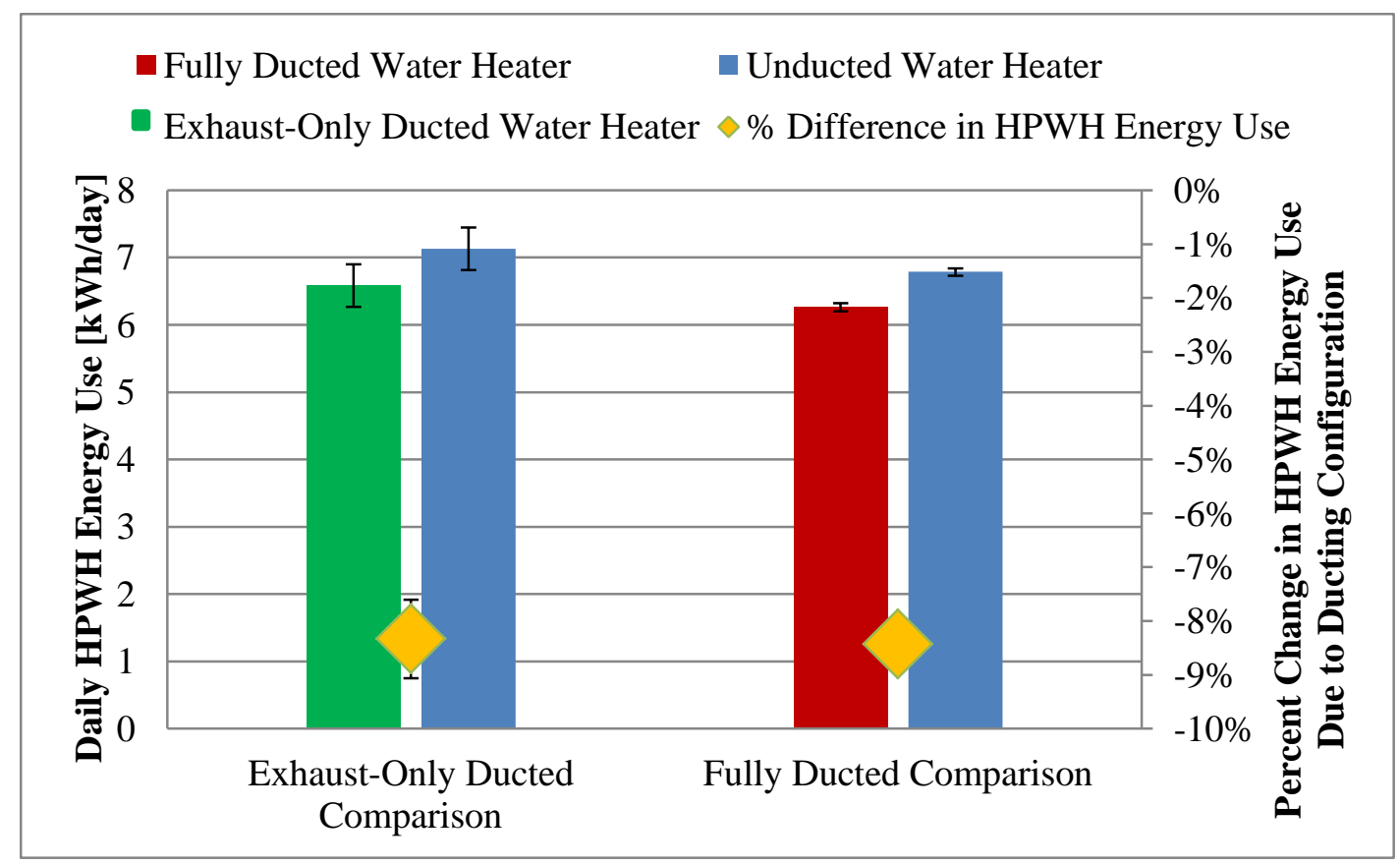

Figure 4.11. Average Daily HPWH Energy Use (kWh/day) During Exhaust-Only Comparison and Fully Ducted Comparison Periods in the Cooling Season

In the heating season, the water heater energy use also was affected by the HPWH closet temperature and by the extent to which localized cooling was mitigated by the ducting configuration. Exhaust-only ducting led to a $7.0 \pm 2.3 \%$ decrease in water heating energy use, due to mitigation of localized cooling. However, as expected, the fully ducted scenario led to a $4.3 \pm 1.8 \%$ increase in water heating energy use due to cooler crawlspace temperatures providing inlet air to the water heater, as shown in Figure 4.12. Crawlspace temperatures were maintained at $44.2 \pm 2.2^{\circ} \mathrm{F}$ throughout the heating season due to ground coupling, several degrees warmer than the average outdoor temperature of $40.0 \pm 9.0^{\circ} \mathrm{F}$. This slightly reduced the water heating penalty of the HPWH. 


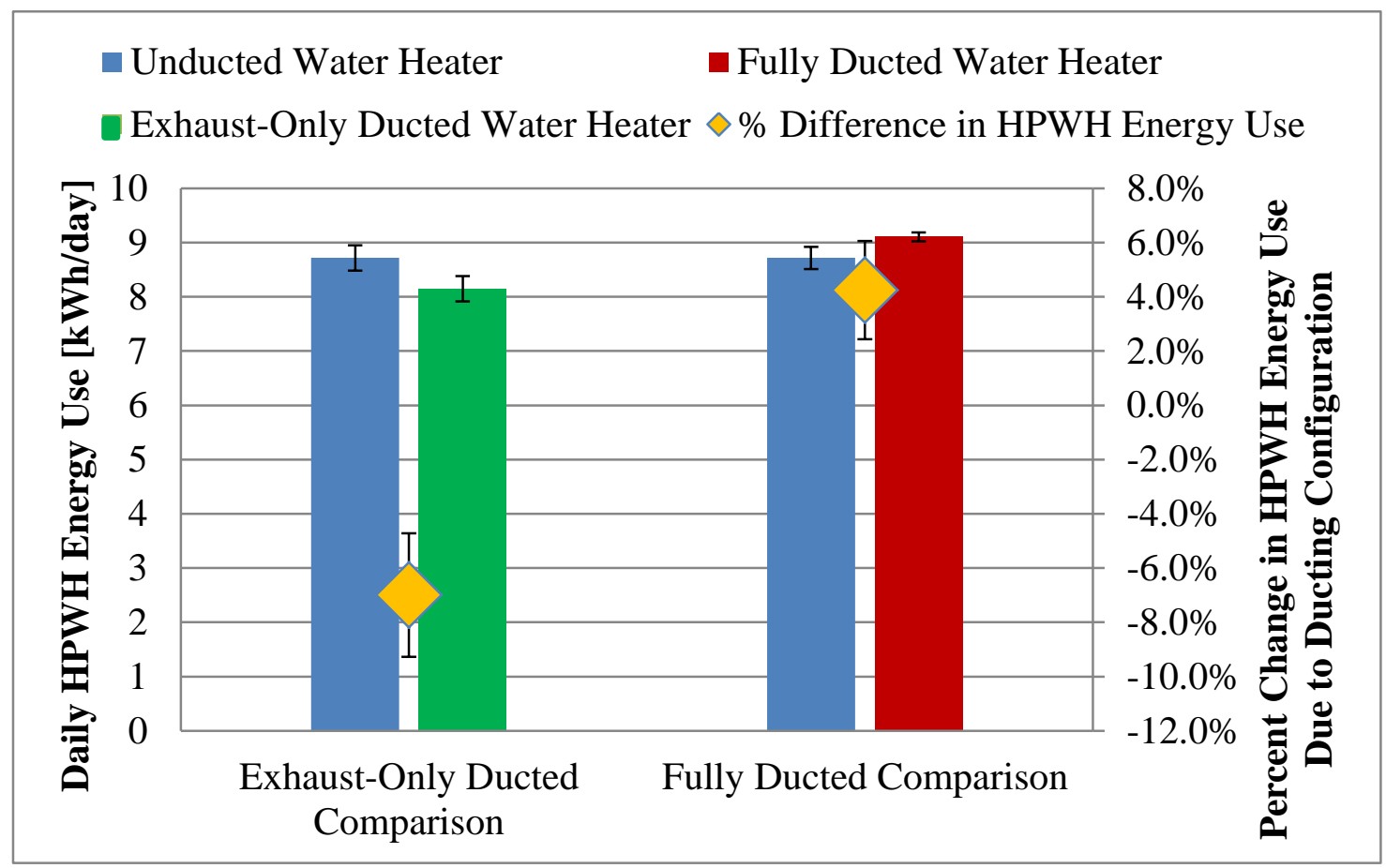

Figure 4.12. Average Daily HPWH Energy Use (kWh/day) During Exhaust-Only Comparison and Fully Ducted Comparison Periods in the Heating Season

Also, recall that the water heaters were operated in "Heat Pump" mode, which disables electric resistance heating. If the "Hybrid" mode were enabled, the impact of full ducting would likely be much more severe, as it may trigger significantly more electric resistance operation. However, it is worth noting that even with the high hot water draw profile deployed and the HPWHs operating in "Heat Pump" mode, they were able to maintain reasonable water delivery temperatures. When in the fully ducted configuration, the hot water outlet temperature dropped to $119^{\circ} \mathrm{F}$, as shown in Figure 4.13. On this day, the crawl space temperature varied between 42 and $48^{\circ} \mathrm{F}^{12}$.

\footnotetext{
${ }^{12}$ Note, the heat pump cut-off temperature has been documented as $45^{\circ} \mathrm{F}$ (GE Appliances 2012; GE Appliances 2014; Larson et al. 2011). However, the thermistor that controls the heat-pump cut-off is located in the HPWH shroud above the evaporator coil, where is experiences some residual heat transfer from the compressor components and standby losses from the tank. As such, the heat pump is capable of operating at measured outdoor (or crawlspace) air temperatures slightly below the documented $45^{\circ} \mathrm{F}$ cut-off temperature.
} 


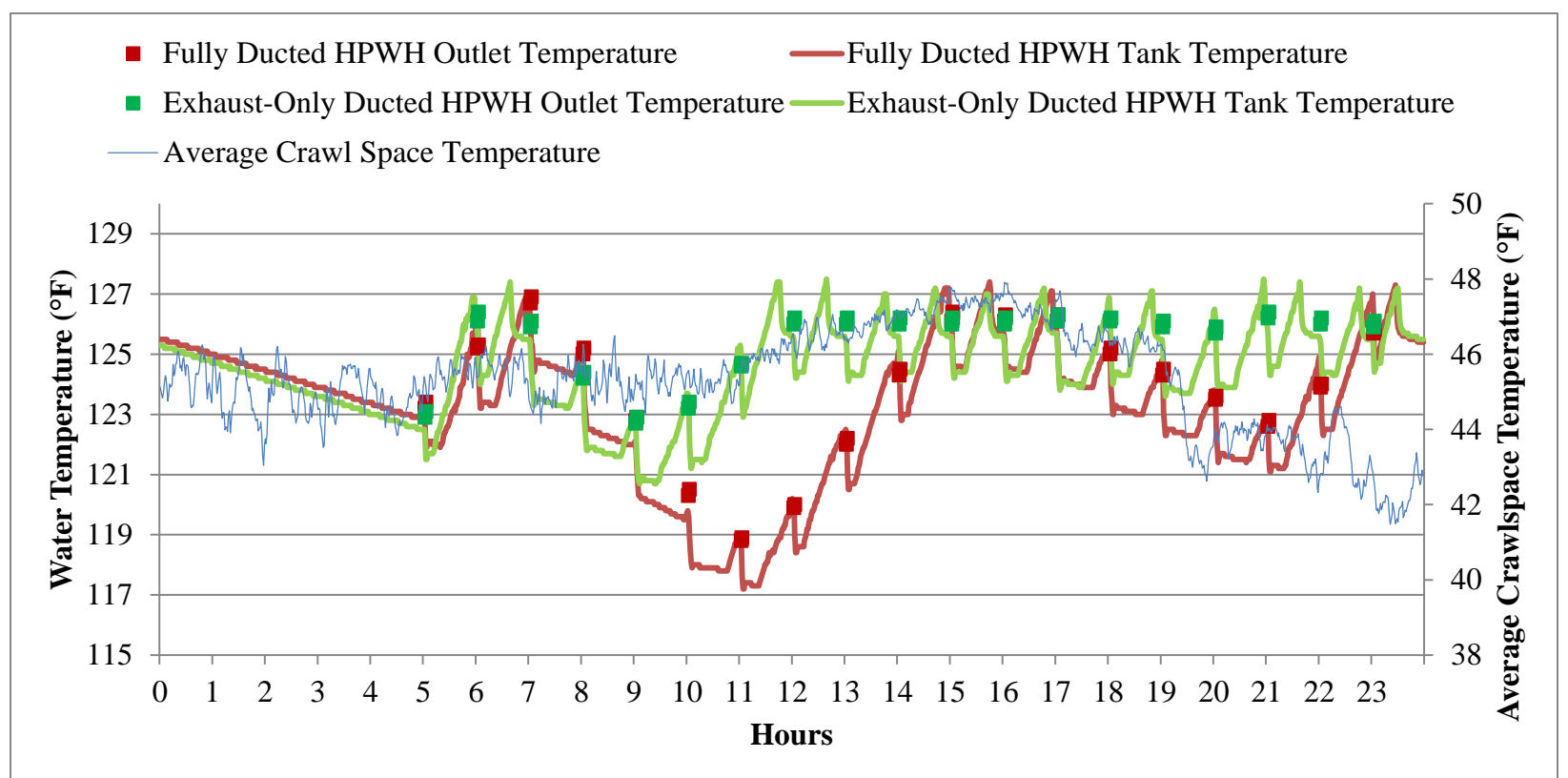

Figure 4.13.HPWH Outlet Temperature and Tank Temperature for the Fully Ducted and Exhaust-Only Cases

Note that the fully ducted HPWH is compared to the exhaust-only ducted HPWH, since water temperature data was not available for the unducted water heater in the heating season. This is due to a catastrophic failure of the unducted HPWH in Lab Home B, caused by a refrigerant leak. The water heater was replaced and re-baselined prior to initiating the heating season experiments. However, the tank and hot water outlet thermocouples were not reinstalled due to time constraints. Since the exhaustonly ducted HPWH uses interior, conditioned air, the performance and hot water delivery are expected to be similar to the unducted HPWH.

These comparisons of water heater energy use and performance do not include fan energy. The fan energy was necessary, due to the ducting configuration, to provide sufficient airflow, as the GE GeoSpring HPWH is not designed for exhaust or full ducting as purchased. The measured airflow through the ducting during these experiments, with the supplemental exhaust fan running, was $166 \mathrm{CFM}$ for the exhaust-only ducting and $117 \mathrm{CFM}$ for the full ducting, both of which are in accordance with installation recommendations (Kresta et al. 2012) for exhaust fan flow rates and GE's recommendations. ${ }^{13}$ Fan energy, in this extreme case, would increase total HPWH energy use approximately $888 \mathrm{Wh} /$ day, on average, or approximately $10 \%$. However, this was not included in the comparison of water heater energy use since, if the HPWH were manufactured to accommodate ducting, the fan could be integrated into the HPWH and fan energy significantly reduced.

\subsection{Whole-House Energy Impacts and Cost-Effectiveness}

While the Lab Home experiments were conducted in the heating season and cooling season to maximize the interaction between the HPWH exhaust and the HVAC system, to assess the annual energy

\footnotetext{
${ }^{13}$ Personal communication with S Schafer, Engineer, GE Appliances, Feb 2013
} 
impacts and cost-effectiveness of ducting the energy impact on water heating energy and space conditioning energy must be compared and the experimental results must be annualized. The experimental results were annualized for the Richland, Washington climate, based on the average number of heating days and cooling days in a year. Specifically, the daily difference in HVAC energy usage and the daily difference in water heater energy usage for the exhaust-only ducted versus unducted comparison are combined to yield a daily whole-house difference in energy use for that case, assuming all other loads are identical. The annual difference in whole-house energy use for the Lab Home with a fully ducted HPWH compared to the Lab Home with an unducted water heater is calculated in a similar manner. The average daily HVAC and water heater energy use calculated during the heating season and the cooling season, respectively, for each experimental period were scaled by the average number of heating days and cooling days, respectively, in Richland. The average number of heating days and cooling days were calculated based on a typical meteorological year by summing the hours that had an outdoor air temperature below $55^{\circ} \mathrm{F}$ or above $75^{\circ} \mathrm{F}$ for heating and cooling hours, respectively, and then dividing by 24 hours to calculate the relative number of days. Note that this approach assumes that the HPWH does not impact the HVAC energy use during the swing season, when it is likely that homes will not be actively conditioned due to mild outside temperatures. While this is likely not an exact calculation, it is a reasonable first approximation of the number of days the home would need to be heating versus cooling in a typical year. The expected annual difference in HVAC, water heater, and whole-house energy use using this method is provided in Table 4.4. As shown in the table, the space conditioning energy consumption overwhelms the difference in water heater energy usage. The difference in space conditioning energy usage is dominated by space heating, which is exaggerated due to the use of an electric resistance furnace in this experiment. A heat pump or gas furnace would demonstrate different energy consumption characteristics.

In general, exhaust ducting is expected to increase whole-house energy use and full ducting is expected to reduce whole-house energy consumption. When the annual difference in whole-house energy use based on the experimental data is calculated based on the degree-day approach discussed above, the exhaust ducting increases annual energy use $714 \pm 446 \mathrm{kWh} / \mathrm{yr}$, and full ducting decreases whole-house energy use $1,031 \pm 411 \mathrm{kWh} / \mathrm{yr}$. These impacts correspond to a $2.9 \pm 1.8 \%$ increase and $4.2 \pm 1.7 \%$ decrease in whole-house energy use for exhaust ducting and full ducting, respectively.

For comparison, the whole-house energy impacts are also calculated assuming $100 \%$ of the thermal load imposed by the HPWH on the space is made up (and/or taken advantage of). This further increases the difference in HVAC energy usage and, thus increases the difference in whole-house energy usage between the exhaust-only or fully ducted water heater and the unducted water heater. This calculation is useful for comparison because it examines the maximum possible interaction between the HPWH and HVAC system. As shown in Table 4.4, the theoretical HVAC system interaction increases the energy penalty of exhaust ducting to $7.3 \pm 4.3 \%$ of annual whole-house energy usage. Similarly, the increase HVAC interaction assumed for the full ducting scenario increases energy savings to $8.8 \pm 3.8 \%$, as compared to the Lab Home with an unducted HPWH. 
Table 4.4. Annual Difference in HVAC, Water Heater, and Whole-House Energy Use (kWh/yr) and Associated Energy Costs Calculated Based on the Experimental Data and the "Theoretical" Difference in HVAC Energy Use

\begin{tabular}{|c|c|c|c|c|c|}
\hline & \multicolumn{5}{|c|}{ Annual Difference in } \\
\hline & $\begin{array}{c}\text { HVAC Energy } \\
\text { Use }[\mathrm{kWh} / \mathrm{yr}]\end{array}$ & $\begin{array}{c}\text { Water Heater } \\
\text { Energy Use } \\
{[\mathrm{kWh} / \mathrm{yr}]}\end{array}$ & $\begin{array}{c}\text { Whole-House } \\
\text { Energy Use } \\
{[\mathrm{kWh} / \mathrm{yr}]}\end{array}$ & $\begin{array}{c}\text { Energy } \\
\text { Cost } \\
(\$ / y r)\end{array}$ & $\begin{array}{r}\text { Lifetime } \\
\text { Cost }(\$)\end{array}$ \\
\hline Exhaust-Only Comparison & $\begin{array}{l}858 \pm 440 \\
(6.2 \pm 3.2)\end{array}$ & $\begin{array}{c}-144 \pm 74 \\
(-6.8 \pm 3.5)\end{array}$ & $\begin{array}{l}714 \pm 446 \\
(2.9 \pm 1.8)\end{array}$ & $\begin{array}{r}86 \\
(2.9)\end{array}$ & 1,306 \\
\hline Fully Ducted Comparison & $\begin{array}{l}-1079 \pm 408 \\
(-7.8 \pm 3.0)\end{array}$ & $\begin{array}{c}48 \pm 49 \\
(2.3 \pm 2.3)\end{array}$ & $\begin{array}{c}-1031 \pm 411 \\
(-4.2 \pm 1.7)\end{array}$ & $\begin{array}{l}-125 \\
(-4.2)\end{array}$ & $-1,982$ \\
\hline $\begin{array}{l}\text { Theoretical Exhaust-Only } \\
\text { Comparison }\end{array}$ & $\begin{array}{l}1953 \pm 1056 \\
(14.1 \pm 7.6)\end{array}$ & $\begin{array}{l}-144 \pm 74 \\
(-6.8 \pm 3.5)\end{array}$ & $\begin{array}{c}1809 \pm 1059 \\
(7.3 \pm 4.3)\end{array}$ & $\begin{array}{r}219 \\
(7.3)\end{array}$ & 2,192 \\
\hline $\begin{array}{l}\text { Theoretical Fully Ducted } \\
\text { Comparison }\end{array}$ & $\begin{array}{l}-2210 \pm 928 \\
(-16.0 \pm 6.7)\end{array}$ & $\begin{array}{c}48 \pm 49 \\
(2.3 \pm 2.3)\end{array}$ & $\begin{array}{l}-2162 \pm 930 \\
(-8.8 \pm 3.8)\end{array}$ & $\begin{array}{l}-262 \\
(-8.8)\end{array}$ & $-2,620$ \\
\hline
\end{tabular}

* Percentage difference in annual energy use estimates are presented as a percent of that equipment load (e.g., the annual difference in HVAC energy use is presented as a percentage of HVAC energy usage).

Table 4.4 also presents the energy costs associated with the whole-house energy use impactsincreased energy costs in the case of exhaust ducting and decreased energy costs in the case of full ducting. The energy costs are presented annually, and as a lifetime cost/savings assuming a lifetime of 10 years and no discounting. This lifetime energy cost can be compared to the cost of ducting. An intake and outlet exhaust duct kit can be purchased from State Water Heaters for a cost of $\$ 75$ (State Water Heaters 2012). However, one must also include the costs of ducting to route the air from the HPWH duct adapter to an appropriate penetration in the building envelope, labor to install the ducting, and associated materials. In Chapter 8-A of the technical support document for the 2010 residential water heater energy conservation standard final rule, DOE assumes an incremental cost of $\$ 459.83$ for adding exhaust and supply ducting to a HPWH (DOE 2010). This assumption includes labor, approximately 50 feet of ducting, the water heater shroud, and associated materials.

Regardless of the cost of ducting, since the installation of exhaust-only ducting was found to increase whole-house energy consumption in this experiment, installation of exhaust-only ducting would not be advised in the Richland climate and this installation configuration. Using the DOE value of $\$ 459.83$, installing full ducting would be cost-effective in this case due to the large heating system penalty in Richland's cold climate for an electric resistance furnace.

Of course, the net energy impacts of HPWH ducting will vary based on climate, heating system type, the specific HPWH, the installation conditions, and the HPWH performance characteristics. More extensive modeling and cost analysis would be required to determine the appropriateness of exhaust-only or full ducting in all of these scenarios. 


\subsection{Conclusions}

The results of this project are analysis based on independent field data that can be applied, both regionally and nationwide, to help enable deployment of HPWHs. Key analysis results include quantification of the whole-house energy impacts of installing a HPWH in a conditioned space with and without exhaust ducting. These results can be used for calibration and refinement of whole-house energy models to characterize the performance of HPWHs in a variety of climate zones and applications. More accurate models can then be used to support the deployment and market penetration of new, highperformance manufactured and site-built homes with HPWHs across a variety of climate zones and installation conditions. The following sections describe the key findings from the Lab Homes evaluation of ducted and unducted HPWHs and recommendations resulting from those findings.

\subsection{Summary of Findings}

HPWHs are a promising technology for substantially reducing water-heating-related energy use. However, concerns have been raised regarding the impact of HPWHs on space conditioning energy when installed in conditioned space in northern climates. Modeling studies have suggested that installing exhaust ducting on HPWHs may mitigate some of this impact. However, this field evaluation of two GE

GeoSpring HPWHs in the PNNL Lab Homes suggests that this may not be the case. Conversely, the data from these experiments suggest that exhaust-only ducting increased space conditioning energy use $4.0 \pm 2.8 \%$ in the heating season as compared to the unducted HPWH, due to increased infiltration of colder outdoor air resulting from depressurization of the interior space. Full ducting was observed to substantially mitigate the impact of the HPWH on the HVAC system. The fully ducted HPWH decreased HVAC energy use $7.8 \pm 2.3 \%$ as compared to the Lab Home with an unducted HPWH.

In addition, the experimental data indicate that the penalty of installing a HPWH in conditioned space may not be as large as modeling studies suggest because buffering by interior walls causes localized cooling in the water heater closet, with very little impact on surrounding interior temperatures. Only approximately $43.4 \pm 12.2 \%$ to $37.2 \pm 4 \pm .7 \%$ of the theoretical space conditioning load was made up by the HVAC system, in the heating and cooling seasons, respectively. The study also verified the benefit of HPWHs installed in conditioned space in providing supplemental cooling, decreasing HVAC energy use by $9.3 \%$ compared to an exhaust-only or fully ducted HPWH. No significant impacts on interior temperatures were observed, as the cooling effect of the HPWH was largely localized in the water heater closet.

Although fully ducting the HPWH was observed to be an effective strategy to mitigate space conditioning impacts of HPWHs installed in conditioned space, this ducting configuration may also increase water heater energy use due to cooler supply air temperatures. This study shows that cooler crawlspace temperatures increased water heater energy use $4.3 \pm 1.8 \%$ for the HPWH operating in "Heat Pump" mode; however, this incremental difference is small compared to the difference in HVAC energy use accomplished by the different ducting configurations.

Therefore, from a whole-house perspective, the net energy impacts of HPWHs installed in conditioned space are driven by the HVAC system interaction. Similarly, the cost-effectiveness of installing ducting on HPWHs will be driven by the HVAC system interaction. In this experiment, full ducting provided a lifetime energy savings of $\$ 1,982$ compared to an unducted HPWH over an assumed 
10 -year life of the water heater. This corresponds to a decrease in whole-house energy costs of approximately $4.2 \%$ annually. Conversely, the exhaust-only ducting increased total energy costs by $\$ 1,306$ over 10 years, or $2.9 \%$ annually, compared to the same unducted HPWH in Richland's heatingdominated climate. For comparison, the whole-house energy impacts were also calculated assuming $100 \%$ of the thermal load imposed by the HPWH on the space is made up (and/or taken advantage of), or the maximum interaction between the HPWH and HVAC system. Assuming this theoretical HVAC system interaction increases the energy penalty of exhaust ducting to $7.3 \pm 4.3 \%$ of annual whole-house energy usage. Similarly, the increase HVAC interaction assumed for the full ducting scenario increases energy savings to $8.8 \pm 3.8 \%$, as compared to the Lab Home with an unducted HPWH.

The magnitude of these energy cost impacts far outweigh the cost of full ducting assumed in this analysis. As such, this experiment suggests that exhaust-only ducting may not be advisable in cold climates, such as Richland, WA. Full ducting was found to cost-effectively reduce whole-house energy use over the lifetime of the water heater. However, additional work is needed to translate these results and develop recommendations for the variety of climates and installation configurations where HPWHs may be installed.

\subsection{Recommendations and Future Experiments}

In general, the Lab Homes evaluation found that installing exhaust-only ducting on a HPWH in conditioned space increased whole-house energy use, while full ducting decreased whole-house energy use. However, to validate these findings and further explore the depressurizations caused by the HPWH with exhaust-only ducting, repeating similar experiments with spatial measurement of differential pressure could identify key sources of infiltration. In addition, conducting an experiment to precisely evaluate the effect of inside walls on buffering of thermal loads could help validate or refute the findings related to the relative magnitude of the interaction between the HPWH and HVAC system, compared to the maximum theoretical interaction. Such inputs could be used to develop more detailed modeling using a multi-zone energy model could confirm/validate space interactions of HPWH duct configurations. Such inputs, along with more detailed modeling using a multi-zone energy model could validate space interactions of HPWH duct configurations.

A calibrated model could then be used to evaluate variability with climate and the relative impacts with different heating and cooling system assumptions. This additional modeling, and associated cost analysis, of HPWH and space conditioning system interactions for a variety of climate zones, HVAC system types, and HPWH operating modes is necessary to assess the cost-effectiveness of ducting and to make formal recommendations regarding appropriate installation of HPWHs under more diverse scenarios. 


\subsection{References}

10 CFR 430.23(e). 2012. "Test Procedures for the Measurement of Energy and Water Consumption Water Heaters." Code of Federal Regulations, U.S. Department of Energy, Washington, D.C. Accessed August 6, 2013, at: http://www.gpo.gov/fdsys/pkg/CFR-2012-title10-vol3/pdf/CFR-2012-title10-vol3sec430-23.pdf.

75 FR 20112. April 16, 2010. “10 CFR Part 430 Energy Conservation Program: Energy Conservation Standards for Residential Water Heaters, Direct Heating Equipment, and Pool Heaters; Final Rule." Federal Register, U.S. Department of Energy. Accessed April 24, 2013 at http://www.regulations.gov/\#!documentDetail;D=EERE-2006-STD-0129-0005.

AirGenerate. 2014. AirTap Hybrid Heat Pump Water Heater Use and Care Manual. ATI3.0.3. AirGenerate, Houston, TX. Available at: http://www.airgenerate.com/downloads/ati303.pdf.

ASTM International. 2010. ASTM Standard E779-10: Standard Test Method for Determining Air Leakage Rate by Fan Pressurization. ASTM International, West Conshohocken, PA.

Christian J, T Gehl, P Boudreaux, J New, and R Dockery. 2010. Tennessee Valley Authority's Campbell Creek Energy Efficiency Homes Project: 2010 First Year Performance Report July 1, 2009-August 31, 2010. ORNL/TM-2010/206, Oak Ridge National Laboratory, Oak Ridge, Tennessee. Accessed August 6, 2013, at http://info.ornl.gov/sites/publications/files/pub26374.pdf

EIA-U.S. Energy Information Administration. 2009. Residential Energy Consumption Survey. U.S. Department of Energy, Washington, D.C. Available at: http://www.eia.gov/consumption/residential/.

GE Appliances, Inc. 2012. GE Appliances Technical Service Guide: GE Hybrid Water Heater. General Electric Company, Knoxville, TN.

GE Appliances, Inc. 2014. GeoSpring ${ }^{T M}$ Hybrid Electric Residential Water Heaters Owner's Manual \& Installation Instructions. General Electric Company, Knoxville, TN. Accessed March 7, 2014, at http://products.geappliances.com/MarketingObjectRetrieval/Dispatcher?RequestType=PDF\&Name=4950292.pdf.

Hendron R and C Engebrecht. 2010. Building America House Simulation Protocols. TP-550-49426, National Renewable Energy Laboratory, Golden, CO. Accessed August 6, 2013, at http://www.nrel.gov/docs/fy11osti/49246.pdf.

Kresta D. 2012. Heat Pump Water Heater Market Transformation Update. Northwest Energy Efficiency Alliance. Portland, OR.

Kresta D, A Winer, and S Vasquez. 2012. Heat Pump Water Heaters - They're here! (this time we mean it). Presentation at the 2012 BPA Efficiency Exchange Utility Summit, Portland, OR. Available at: http://www.bpa.gov/Energy/N/utilities sharing ee/Utility Summit/Workshop2012/Heat Pump Water H eaters.pdf.

Larson B, M Logsdon, and D Baylon. 2011. Residential Heat Pump Water Heater Evaluation: Lab Testing \& Energy Use Estimates. Available at:

http://www.bpa.gov/energy/n/emerging_technology/pdf/HPWH_Lab_Evaluation_Final_Report_2011110 9.pdf.

Larson B and M Logsdon. 2012. NEEA Report: Laboratory Assessment of General Electric GeoSpring ${ }^{T M}$ Hybrid Heat Pump Water Heater. REPORT \#09282012. Ecotope, Inc. for the Northwest Energy Efficiency Alliance, Portland, OR. 
Larson B, A Hadley, and J Harris. 2012. Heat Pump Water Heaters: Tier 2 - Ducted Interior

Installations. Presented to the Pacific Northwest Regional Technical Forum February 14, 2012, by Adam Hadley and Jeff Harris, Portland, OR. Accessed August 6, 2013, at

http://rtf.nwcouncil.org/meetings/2012/02/HPWH Ducted Interior Installations Provisional Proposal 0 21412_v5.pptx.

Larson B and T Hewes. 2012. High Performance Manufactured Homes. Presented to the Pacific Northwest Regional Technical Forum, May 15, 2012, by Adam Hadley and Ben Larson, Portland, OR. Accessed August 6, 2013, at http://rtf.nwcouncil.org/meetings/2012/05/HPMH_Proposal_20120515_v2a.ppt.

Lutz J, A Renaldi, A Lekov, Y Qin, and M Melody. 2011. Hot Water Draw Patterns in Single-Family Houses: Findings from Field Studies. LBNL-4830E. Lawrence Berkeley National Laboratory, Berkeley, CA.

Maguire J, J Burch, T Merrigan, and S Ong. 2013. Energy Savings and Breakeven Cost for Residential Heat Pump Water Heaters in the United States. NREL/TP-5500-58594, National Renewable Energy Laboratory, Golden, CO. Available at: http://techportal.eere.energy.gov/techpdfs/HPWH mapping.pdf.

NEEA-Northwest Energy Efficiency Alliance. 2013. Northern Climate Heat Pump Water Heater Specification - Version 5.0. Northwest Energy Efficiency Alliance, Portland, OR. Available at: http://neea.org/northernclimatespec.

NEEA-Northwest Energy Efficiency Alliance. 2014. Northern Climate Heat Pump Water Heaters Qualified Products List. Northwest Energy Efficiency Alliance, Portland, OR. Available at: http://neea.org/northernclimatespec.

Nelson J, M Beyerle, J Kern, and E Rodriguez. 2012. "Hybrid electric water heater with external discharge ducting." US Patent 20120023990 A1. General Electric Company. U.S. Patent \& Trademark Office, Washington D.C. Available at: http://appft1.uspto.gov/netacgi/nph-

Parser?Sect1=PTO1\&Sect2=HITOFF\&d=PG01\&p=1\&u=\%2Fnetahtml\%2FPTO\%2Fsrchnum.html\&r=1

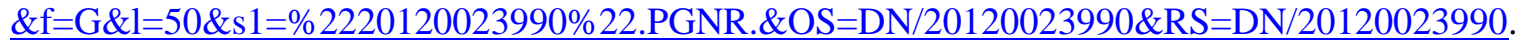

Northwest Power and Conservation Council. 2010. Sixth Northwest Conservation and Electric Power Plan. Northwest Power and Conservation Council, Portland, OR. Available at: http://www.nwcouncil.org/energy/powerplan/6/plan/.

State Water Heaters. 2012. Distributor Price Book. SMBPB00308, State Water Heaters, Ashland City, TN. Available at: http://www.spesifikasii.com/pdf/smbpb00208-price-book-state-rep-site-state-waterheaters-3854.pdf

The Energy Conservatory. 2012. Minneapolis Blower Door Operation Manual for Model 3 and Model 4 Systems. The Energy Conservatory, Minneapolis, MN. Available at:

http://www.energyconservatory.com/sites/default/files/documents/mod_3-4_dg700_-_new_flow_rings__cr_-_tpt_-_no_fr_switch_manual_ce_0.pdf

Widder S, G Parker, M Baechler and N Bauman. 2012. Side-by-Side Field Evaluation of Highly Insulating Windows in the PNNL Lab Homes. PNNL-21678, Pacific Northwest National Laboratory, Richland, WA. Accessed April 24, 2014, at http://labhomes.pnnl.gov/experiments/windows.stm.

Widder S, J Peterson, G Parker, and M Baechler. 2013. Demand Response Performance of GE Hybrid Heat Pump Water Heater. PNNL-22642. Pacific Northwest National Laboratory, Richland, WA. Available at: http://www.pnnl.gov/main/publications/external/technical_reports/PNNL-22642.pdf.

Wilson E and D Christensen. 2012. Heat Pump Water Heater Modeling in EnergyPlus. NREL/PR-5500-54318, National Renewable Energy Laboratory, Golden, CO. Available at: http://www.nrel.gov/docs/fy12osti/54318.pdf . 



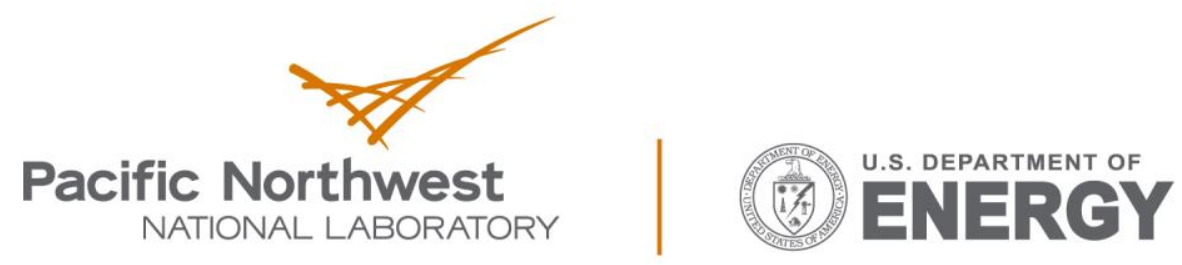

Proudly Operated by Battelle Since 1965

902 Battelle Boulevard

P.O. Box 999

Richland, WA 99352

1-888-375-PNNL (7665)

www.pnnl.gov 